\title{
8. UPPER TRIASSIC (RHAETIAN) CARBONATE ENVIRONMENTS, WOMBAT PLATEAU, NORTHWEST SHELF, AUSTRALIA ${ }^{1}$
}

\author{
Peter E. Borella, ${ }^{2}$ Naci Görür, ${ }^{3}$ Thierry Dumont,${ }^{4}$ Ann Stefani,,${ }^{5}$ and Tracy Lewis ${ }^{5}$
}

\begin{abstract}
During Leg 122 of the Ocean Drilling Program, Upper Triassic (Rhaetian) limestones were recovered from Sites 761 and 764 beneath the Wombat Plateau. Carbonate wackestones and mudstones, representing lagoonal to intertidal environments, are present at Site 761. Siliciclastic sediments (claystones) from floods or nearby deltaic systems were episodically mixed with these shallow-water carbonates. The carbonates and siliciclastics are interpreted as an upward-shoaling sequence. Fringing, pinnacle-shaped reefs with lateral carbonate wedges occupy the outer margin of the plateau (Site 764). The reefs appear to be fault controlled and are more extensive than originally postulated (Williamson et al., 1989). The presence of the reefs represents the first discovery of such environments on the Australian Northwest Shelf.

Geochemical well logs correlate with the seismic records and with the petrology. Based on the calcium, silicon, iron, and chlorine concentrations, the Rhaetian sediments at Sites 761 and 764 are divided into two and three geochemical units, respectively. Hiatuses or unconformities representing periods of subaerial exposure, sea-level standstill, or nondeposition are present in the cores and logs. These zones correlate with reduced-amplitude seismic horizons that pass through the reef environment. The porosity of the reefs and correlation of seismic low-velocity zones (Williamson et al., 1989) with iron and silicon enrichment in the carbonates suggest subaerial exposure. Thus, there may be widespread porosity development on the Wombat Plateau, which has implications for petroleum exploration in the area.

Faults beneath the reefs shown on seismic profiles, pre- and post-Rhaetian faults, regional tilting, and petrographic evidence documenting subaerial exposure suggest that tectonism is the dominant force controlling structure, facies distribution, and sea-level fluctuation on the Wombat Plateau. The Wombat Plateau was also locally uplifted and subaerially eroded during the Early Jurassic. Eustatic changes may be present (Dumont, this volume; Röhl et al., this volume), but tectonic events, coupled with climate and basin geometry, disrupt the eustatic signal. Therefore, the Wombat Plateau, a tilted horst, should not be used as a model site to test worldwide eustatic changes during the Rhaetian.
\end{abstract}

\section{INTRODUCTION}

During Leg 122 of the Ocean Drilling Program (ODP), Upper Triassic limestones of Rhaetian age were penetrated at Sites 761 and 764 . The sites are located on the Wombat Plateau, which is a subplateau of the Exmouth Plateau (Fig. 1). These shelf limestones, particularly the reefal limestones recovered at Site 764, represent the first discovery of Triassic reefal material in the region of the Australian Northwest Shelf (Williamson et al., 1989). Recovery in the drilled sequences was approximately $20 \%$, but the limestones recovered, along with the well logs and seismic records, allow a reconstruction of the sedimentary environment.

The purposes of this paper are to (1) examine the limestones recovered at Sites 761 and 764 through megascopic and microscopic study, (2) define and determine the facies and microfacies present, (3) correlate the facies to the geochemical downhole logs and seismic records, (4) suggest depositional models for the facies, and (5) relate the depositional setting to tectonism and eustacy. Some of the interpretations of facies and depositional environments and the tectonic history of the

1 von Rad, U., Haq, B. U., et al., 1992. Proc. ODP, Sci. Results, 122: College Station, TX (Ocean Drilling Program).

2 Saddleback College, 2800 Marguerite Parkway, Mission Viejo, CA 92692, U.S.A.

Jeologi Bolumu, Maden Fakultesi, Istanbul Technical University, Tesuikiye, Istanbul, Turkey.

4 Institut Dolomieu, U.A. 69 CNRS, 15 Rue Maurice Gignoux, 38031 Grenoble Cedex, France.

5 Department of Geology, California State University, Fullerton, Fullerton, CA 92631, U.S.A. area have already appeared in Williamson et al. (1989) and von Rad et al. (1989).

\section{SETTING}

The Exmouth Plateau and in particular the Wombat Plateau are underlain by part of the Westralian Superbasin (Yeates et al., 1987), which forms a portion of the Australian continental margin. The Westralian Superbasin (geosyncline) is a $10-\mathrm{km}$-thick contiguous Permian through Mesozoic sequence of sedimentary rocks that extends along the western margin of Australia (Bradshaw et al., 1988). The Exmouth Plateau is approximately $600 \mathrm{~km}$ long by $350 \mathrm{~km}$ wide with a water depth ranging between 800 and $4000 \mathrm{~m}$. The Wombat Plateau is a subplateau separated from the main Exmouth Plateau by the deep Wombat half-graben. The Exmouth Plateau and the Wombat Plateau are bounded by the Argo Abyssal Plain to the north, the Gascoyne Abyssal Plain to the northwest, and Cuvier Abyssal Plain to the southwest (Fig. 1). The continent/ocean boundary coincides roughly with the escarpment between the Exmouth Plateau (continental crust) and the surrounding oceanic basins. To the east, the plateau is separated from the Northwest Shelf by the Carnarvon (west) Basin, which consists of the fault-bounded Exmouth, Barrow, Dampier, and Beagle sub-basins. The sub-basins trend southwest to northeast (Yeates et al., 1987). The geologic history of the Exmouth and Wombat plateaus has been discussed by many authors, including Falvey and Veevers (1974), Veevers and Johnstone (1974), Veevers and Cotterill (1979), Willcox and Exon (1976), Exon and Willcox $(1978,1980)$, von Rad and Exon (1983), Exon and Williamson (1988), Williamson and Falvey (1988), and Veevers (1988). 


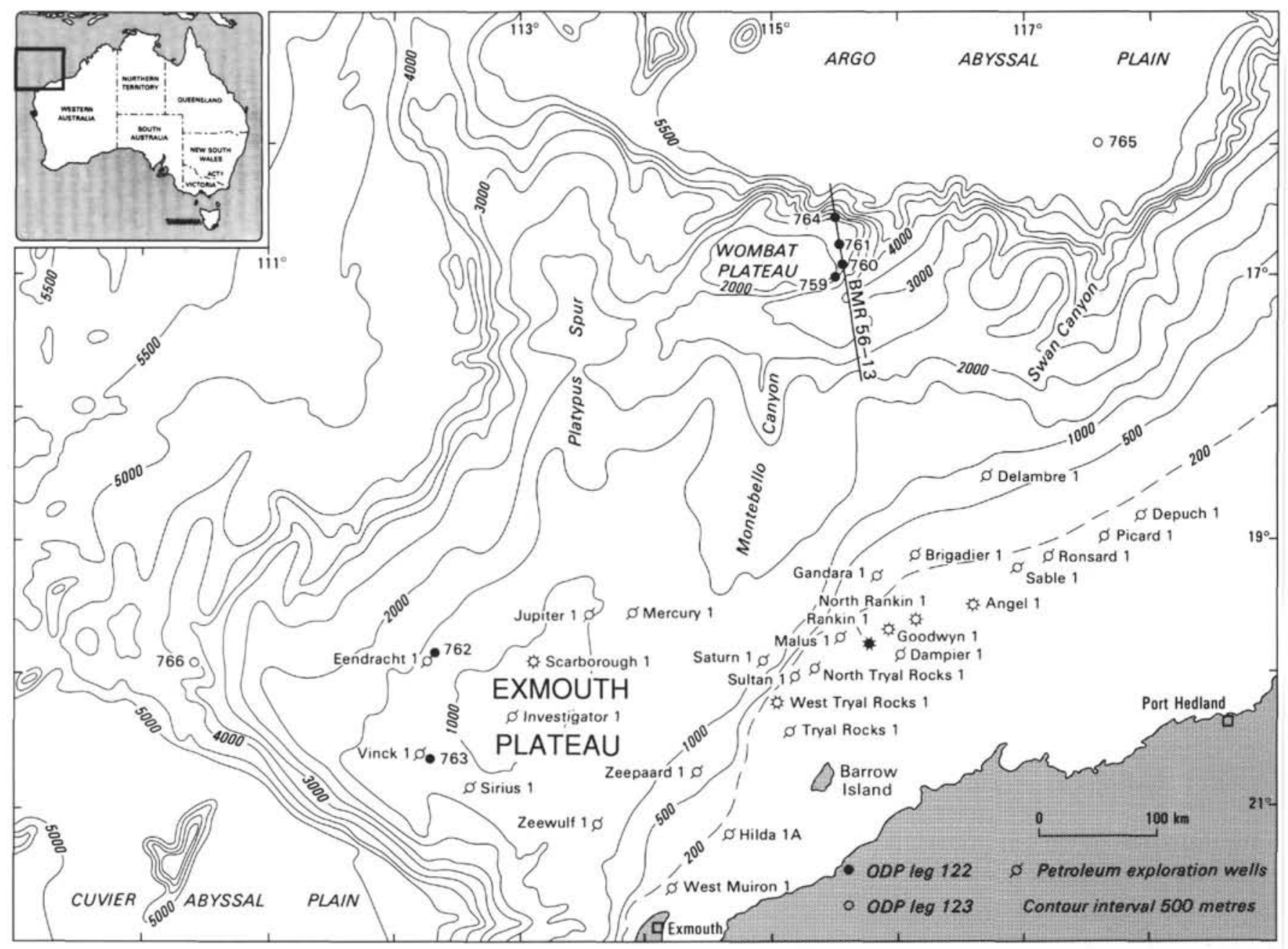

Figure 1. Index map and site locations, Leg 122, Exmouth and Wombat plateaus.

The Exmouth Plateau is a rifted and deeply subsided continental fragment that is covered by 8 to $10 \mathrm{~km}$ of Phanerozoic sedimentary rocks (Exon and Willcox, 1978). The Wombat Plateau is a horst that was uplifted during various Late Triassic rifting events. During the Jurassic, the Wombat Plateau was uplifted above sea level and subsequently eroded. During the Early Cretaceous (Neocomian), subsidence produced by breakup of the Argo Abyssal Plain (Leg 123 Shipboard Scientific Party, 1989) submerged the horst. The large regional angular unconformity on the seismic profile (Fig. 2) that marks this event consists of Upper Triassic sediments unconformably overlain by a veneer of Cretaceous and Cenozoic pelagic sediments.

Geologic evidence indicates that extensional tectonics along with marked attenuation of the continental crust began in the Permian along this northern margin of Gondwana (Fairbridge, 1982; Williamson and Falvey, 1988; Mutter et al., 1989). Rifting began in the Triassic and thick sequences of terrigenous to shallow-marine siliciclastic sediments accumulated. During the Carnian, shallow-water sediments were overlain by marginal marine clastic sediments and alternating shallow-water carbonates and deltaic sediments (Haq, von Rad, O'Connell, et al., 1990). Overlying these Carnian sediments is a 300 -m-thick Norian sequence consisting of shallowmarine limestones interbedded with fluviodeltaic siltstones and claystones. This sequence grades upward into deltaic coastal plain facies with algal mats, coal seams, and root horizons. Later, in the Rhaetian, shallow-water marine carbonate and reefal sediments were deposited. These Upper Triassic (Rhaetian) sediments (Haq, von Rad, O'Connell, et al., 1990) are the topic of this paper.

\section{METHODS}

Core summaries and lithologic descriptions (Haq, von Rad, O'Connell, et al., 1990) were supplemented with a petrographic examination of 140 thin sections that were prepared aboard JOIDES Resolution. The locations of the samples from which the thin sections were prepared are given in the Site 761 and 764 summaries (Haq, von Rad, O'Connell, et al., 1990). The thin sections are maintained in a reference library by the ODP Curator for use upon request.

The thin sections were stained with Alizarin Red-S and potassium ferricyanide and photographed. Data sheets were compiled that included the relative abundance of allochemical vs. orthochemical constituents, grain textures, cements, neomorphic features, and sedimentary structures. The classification systems of Dunham (1962) and Folk (1962) were used. Descriptions in Bathurst $(1966,1971)$ were used as a basis for identifying diagenetic and neomorphic characteristics. Flügel (1982), Scholle (1979), and Scholle et al. (1983) were used to aid in the identification of allochemical fossil grains and the interpretation of microfacies and their environments. 

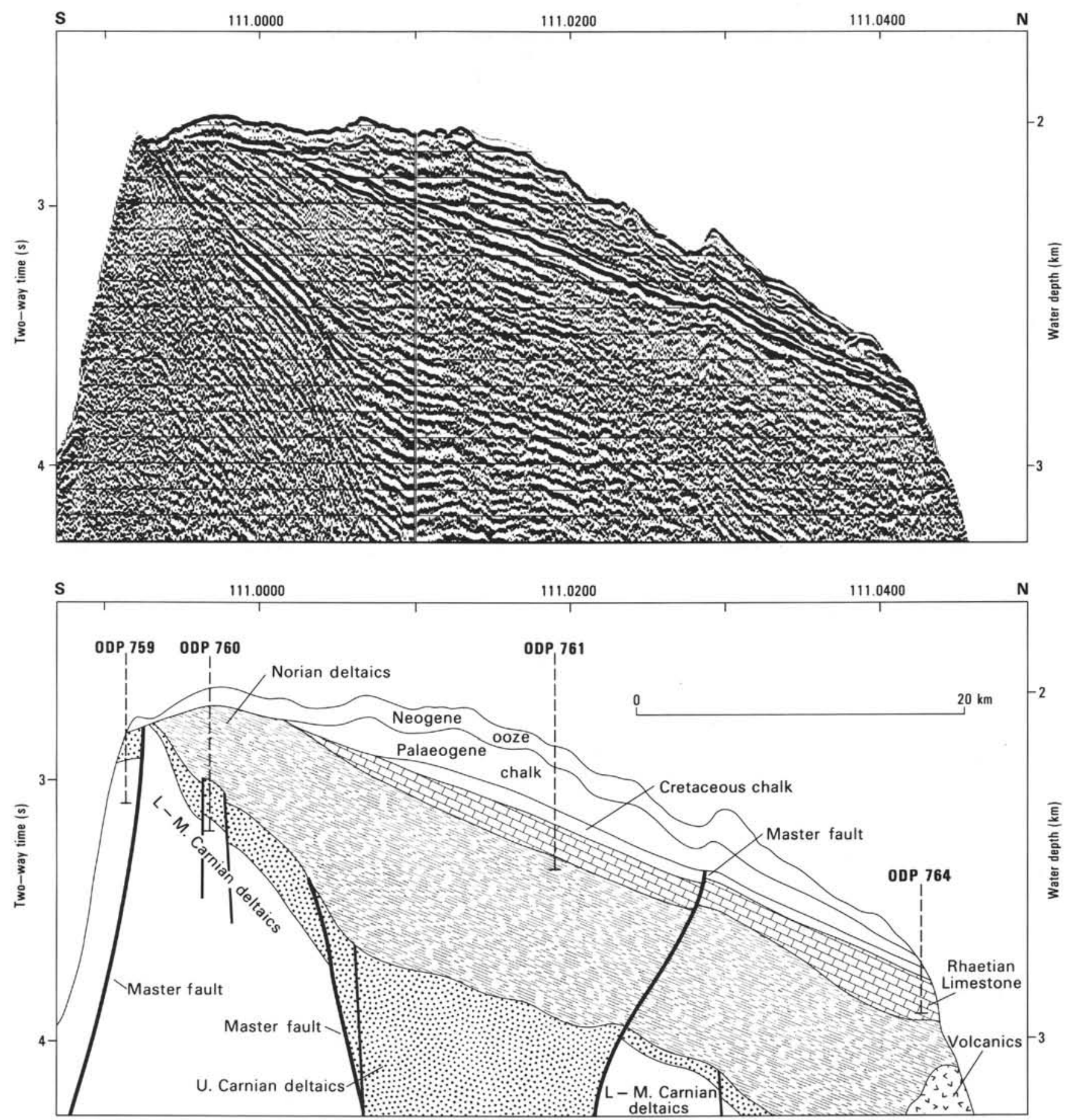

Figure 2. Regional seismic data and interpretation of structure of seismic line BMR 56-13, Wombat Plateau. See Figure 1 for location (after Williamson et al., 1989).

A summary of the megascopic and microscopic facies is presented for each site. Geologic units are described from bottom to top.

\section{GEOPHYSICAL WELL LOGS}

Detailed descriptions, principles, and interpretations of the wireline geophysical well logs obtained from Sites 761 and 764 are provided in Rider (1986), Haq, von Rad, O'Connell, et al. (1990), the Wireline Logging Manual (Borehole Research Group, 1989), and Pratson et al. (this volume). For completeness, a brief summary of the downhole logs obtained from Sites 761 and 764 used in this paper is given here.

\section{Induced Gamma-Ray Spectroscopy Tool}

The relatively new induced gamma-ray spectroscopy tool (GST) has a major advantage over standard logging tools in that it can be run inside the drilling pipe. Thus, the GST can be used in intervals that could not otherwise be logged due to hole instability. 
The GST contains a neutron accelerator that generates pulses of 14-meV neutrons. The neutrons lose energy through scattering interactions with atoms in the surrounding sediments and rocks. When the neutrons reach thermal energy levels they are captured by elemental nuclei. Gamma rays produced by capture are emitted and measured by a spectrometer consisting of a sodium iodide detector and a multichannel analyzer. Each element has a unique emission spectrum, and analyses of the combined spectra provide an estimate of the elemental composition of the lithologic units.

Aboard JOIDES Resolution, the GST calculates the proportions of six elements- $\mathrm{Ca}, \mathrm{Cl}, \mathrm{Si}, \mathrm{Fe}, \mathrm{H}$, and $\mathrm{S}$. The graphs generated by the GST represent the relative amounts of each element compared with the rest. Ratios of these elements are used to interpret the lithology, salinity, and porosity. The relative abundances of the elements can also provide clues to the lithologic and geochemical characteristics of the sediments and rocks. Silicon and calcium can be related directly to silicate and carbonate minerals. The relative proportion of hydrogen is an indicator of porosity. Iron provides an estimate of clay minerals and oxidized zones that concentrate insoluble residues rich in iron oxides. Sulfur can be related to the occurrence of anhydrite and/or gypsum. In predominantly carbonate environments such as Sites 761 and 764, high iron concentrations may indicate subaerial exposure surfaces where iron has been concentrated in oxide form. The relative abundance of chlorine may be an indicator of the salinity of pore waters included with the rocks and sediments.

\section{PETROLOGY}

\section{Site 761}

Borings at Site 761 (Fig. 3) revealed extensive marine carbonates of Rhaetian age, with great variation in lithology and texture. The Rhaetian sequence is approximately $163 \mathrm{~m}$ thick and has been divided into two units, IV and V. On the basis of different proportions of carbonate and terrigenous constituents Unit V was subdivided into Subunits VA and VB. Unit and subunit designations have been maintained to avoid confusion with the site chapters (Haq, von Rad, O'Connell, et al., 1990). Wackestones predominate throughout the section. Boundstones are more abundant at the base of Subunit VA. Packstones and grainstones are common in the upper part of Unit IV.

\section{Unit V (422.4-338.3 $m$ below seafloor [mbsf])}

Unit V is an 84-m-thick sequence of interbedded carbonate mudstones to grainstones with calcareous claystones to silty claystones. The rocks are gray to dark gray; the more argillaceous sediments are darker.

\section{Subunit VB (422.4-399.3 mbsf)}

The primary lithology present in 23-m-thick Subunit VB is calcareous to silty claystones with minor carbonate mudstones, wackestones, and grainstones. The lower part of the subunit contains several $5-\mathrm{cm}$ - to 1 -m-thick beds consisting of packstone to wackestone with erosional scours or load casts at the base. These graded beds contain abundant shell fragments, and in particular crinoid fragments. The shells are oriented parallel to bedding. The graded wackestones and packstones are interbedded with bioturbated wackestones and mudstones. Some quartz sandstone and siltstone beds are present at the base of the subunit. The quartz sand is well sorted and grades downward into a very coarse, intraclast-rich horizon that is $20 \mathrm{~cm}$ thick. Intraclasts containing crinoids, shell fragments, and ooids are included in a fossiliferous sandstone matrix. The basal contact is probably unconform- able with the underlying unit, which is Norian in age (Haq, von Rad, O'Connell, et al., 1990). Above the lower part of the subunit is a $6.3-\mathrm{m}$-thick sequence of carbonate grainstone to mudstone with minor calcareous to silty claystones. The upper $15 \mathrm{~m}$ consists primarily of 0.70 - to 2.0 -m-thick intervals of calcareous to silty claystone with rare 60 -cm-thick packstone to grainstone beds that grade upward into wackestones or mudstones.

The wackestones consist mainly of fragments of echinoderms, mollusks, corals, and small benthic foraminifers in a dolomitic matrix. Echinoderms, both whole and broken, are mainly crinoid plates and spines. Coral allochems consist of neomorphic calcite, which has inverted from aragonite, and show a partly or wholly preserved internal architecture. The growth of the neomorphic spar probably occurred simultaneously with the step-by-step dissolution of the aragonite (Schlanger, 1964). Mollusk fragments commonly show micritic envelopes and infillings and are preserved as casts without internal structure (PI. 1, Figs. 1 and 4).

Packstones within this subunit contain a wide variety of both whole and broken fossils in a micrite or microspar matrix. Common allochems are mollusks, corals, benthic foraminifers, algal fragments, pelmatozoans, and calcareous sponge spicules. Many of the packstones show varying degrees of hematite or manganese staining, ranging from small spots and aureoles (PI. 1, Fig. 3) to a pervasive reddish staining of the matrix. Other forms of diagenetic alteration of the packstone include the filling of solution-cavities, inversion, and recrystallization.

Grainstones are found mainly at the base of the subunit and contain abundant angular to subrounded quartz and feldspar, as well as allochems similar to those in the wackestones and packstones.

\section{Subunit VA (399.3-338.3 mbsf)}

Subunit VA contains approximately $61 \mathrm{~m}$ of mud-supported carbonates: mudstone, parallel-laminated and argillaceous wackestone, and minor peloid-skeletal packstone, interbedded with thin calcareous to silty claystone layers (Haq, von Rad, O'Connell, et al., 1990). The basal $23 \mathrm{~m}$ consists of packstone to grainstone with subordinate wackestone. Overlying the basal interval is $7.5 \mathrm{~m}$ of rhythmically interbedded, bioturbated carbonate mudstone-wackestone and calcareous silty claystone. The interbeds range from 5.0 to $90 \mathrm{~cm}$ in thickness. Above this interval lies a $27-\mathrm{m}$ sequence of $0.3-$ to 1.5 -m-thick bioturbated carbonate mudstone interbedded with thin calcareous claystone. The upper $3.5 \mathrm{~m}$ consists of alternating bioturbated wackestone and parallel-laminated argillaceous wackestone with minor packstone.

In thin section, the wackestones are rich in mollusks (gastropods predominate) and pelmatozoan fragments, with less abundant foraminifers and coralline algae. Dolomitization appears to be selective and affects the poorly sorted micritic matrix. Dolomite crystals are subhedral and range from fine to medium sand size.

The lower portion of the unit consists of fine- to coarsegrained hematite-stained fossiliferous grainstone and boundstone. The grainstone is primarily composed of skeletal grains and peloids that have been cemented by fine to medium sparry calcite (Pl. 1, Fig. 1). Echinoderm fragments predominate over other skeletal allochems and commonly have syntaxial overgrowth cements. Other skeletal allochems include mollusks, coralline red algae, and small benthic foraminifers. Many of the grains have been extensively bored (Pl. 1, Fig. 1). The borings are commonly filled by micrite.

The peloids commonly show relic internal structures that suggest that the grains are the remains of small benthic 


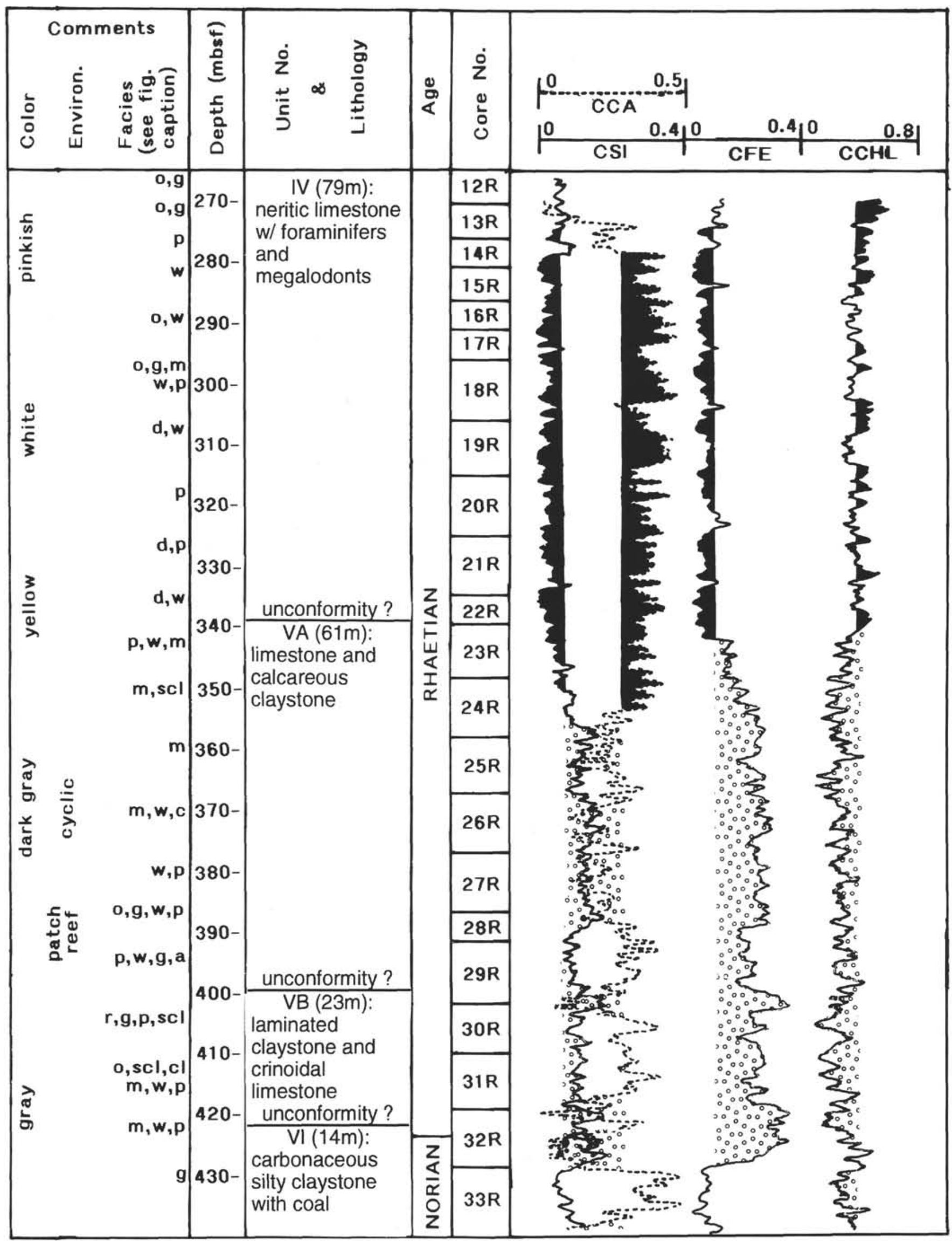

Figure 3. Geochemical logging results from Hole 761C. Facies are silty claystone (scl), claystone (cl), dolomite (d), oolites (o), rudstone (r), grainstone $(\mathrm{g})$, algal $(\mathrm{a})$, packstone $(\mathrm{p})$, wackestone $(\mathrm{w})$, and mudstone $(\mathrm{m})$. Logs are calcium concentration $(\mathrm{CCA})$, silica concentration $(\mathrm{CSI})$, iron concentration (CFE), and chloride ion concentration (CCHL). Shaded and dotted zones indicate geochemical intervals. 
foraminifers or fragments of coralline red algae. In addition, the peloids commonly have micritic coatings. Micritization is caused by boring organisms, particularly algae. Skeletal grains are transformed to micrite by alternating boring and infilling of the borings by micrite cement (Bathurst, 1966, 1971). Micritization proceeds from the outside of the grains inward. A micritic envelope results when alteration is incomplete.

Coralline red algae and coral boundstone are present at the base of the subunit. Microscopically, the boundstone consists of corals, coralline red algae, benthic foraminifers, mollusks, echinoderms, and peloids in a micritic matrix (PI. 1, Figs. 1 and 2). Micritic envelopes and evidence of boring algae and fungi are present. The wall structure of corals is entirely obliterated because the original aragonite was replaced by calcite during early diagenesis. Patchy areas of dolomitization are also present. In thin section, these units are wackestone or packstone rather than boundstone (PI. 1, Fig. 2). It is uncertain whether this lithofacies represents a welded growth structure of reefal organisms infilled by detritus to give a packstone texture or whether it is a fossiliferous wackestonepackstone that was formed by in-situ fragmentation and deposition of red algae and corals. Considering its thickness and the presence of corals and coralline red algae in growth position, we interpret it to be reefal in origin.

\section{Unit IV (338.3-259.5 mbsf)}

Unit IV is characterized by a regressive or shallowingupward sequence (inverse graded bedding). The lower portion of the unit is dominated by low-energy carbonate rocks such as wackestone and the upper portion consists mainly of higher energy grainstone deposits (Fig. 3).

Unit IV is approximately $79 \mathrm{~m}$ thick. Megascopic examination of the samples in this interval shows a variety of lithofacies ranging from grainstone to wackestone/packstone and mudstone, which indicates a shallow subtidal to intertidal environment. Fossil allochems are abundant and include the thick-shelled Megalodon sp., other mollusks, corals, sponges, calcareous algae, and benthic foraminifers (e.g., Triasina sp.).

Fossiliferous wackestone dominates the basal carbonates. These wackestones, dolomitized in part, can be differentiated further on the basis of the fossil content. At the base of the section, the wackestones contain sponge spicules and thinshelled pelagic bivalves, with less abundant ostracodes, pelagic foraminifers, bryozoa, and mollusk fragments (Megalodon sp.) (Pl. 2, Fig. 3). Higher in the section the wackestones contain abundant mollusk fragments, echinoderms, and corals with minor ostracodes, bryozoa, and sponge spicules. Some of the original wall structure of the mollusks is preserved (PI. 2, Fig. 4). Echinoderms are fragmented and angular (Pl. 2, Fig. 3 ), and corals are usually inverted to sparry calcite. Higher in the section more benthic foraminifers, including miliolids and Triasina sp., are present in the wackestones. The foraminifers have vague outlines produced by recrystallization and are commonly dissolved, showing a moldic porosity. Mollusks, echinoderms with syntaxial overgrowths, and algae are also present.

The dolomite in these fossiliferous wackestones is fine to medium grained and displays relic ghosts of original grains or peloids. Dolomite overgrowths are also visible. The dolomite is secondary in origin.

The carbonates in the upper part of Unit IV (PI. 2, Figs. 1 and 2) are grainstone and packstone with abundant benthic foraminifers, ooids, and peloids. A fossiliferous wackestonepackstone interval is interbedded with the grainstone-packstone facies.

Benthic foraminifers in these grainstones are tentatively identified as Triasina sp., miliolids, involutinids, ammodisc- ids, and nodosariids (PI. 2, Fig. 2). Other allochems include echinoderms, mollusks, and minor coralline red algae, corals, pellets, intraclasts, and scarce lithoclasts. Sparry calcite is the cement. Most foraminifers show signs of replacement by micrite or microspar (PI. 2, Fig. 2). Dissolution of foraminifer tests leaves moldic porosities (Pl. 2, Fig. 2).

Above the grainstones are wackestones to packstones and a dolomite layer. The dolomite within this interval is characterized by a mosaic of fine to very fine anhedral crystals with ghost structures, relic fossils, and vuggy (moldic) porosities. An algal mat is present in Section 122-761C-15R-1, 38-41 cm.

The fossiliferous wackestone/packstone contains casts of mollusks, pelmatozoan fragments, and minor amounts of benthic foraminifers. Foraminifer grainstones and ooidpeloid-foraminifer packstones to grainstones lie stratigraphically above the wackestone/packstone facies. The foraminifer grainstones are similar to those lower in the unit. The ooidpeloid-foraminifer grainstones (PI. 2, Fig. 1) have abundant benthic foraminifers (Triasina sp.) and minor amounts of mollusks, echinoderms, and coralline red algae. Many foraminifers are peloidal as a result of micritization and recrystallization. The ooids are spherical or ellipsoidal and have poorly preserved concentric and radial structures. Because most of them have a large nucleus with a single laminae they are considered to be superficial ooids. The nuclei are composed primarily of microsparite. The skeletal grains mixed with the ooids commonly have micritic envelopes that probably formed by boring algae and fungi, although they may also represent the micritized cortices of the ooids.

\section{Environments of Deposition for Site 761}

In general, the Rhaetian carbonates are interpreted as an upward-shallowing sequence. At the base of the Rhaetian, interbedded black claystones and carbonate rocks have graded beds and erosional scours. The depositional environment was relatively deep, below wave base. The clastic and carbonate sediments may have been transported to the depositional site by turbidity currents, sediment gravity flows, or sediment input from distant deltaic systems. More than one source was contributing sediments to the area as evidenced by the carbonate and siliciclastic components in the rocks (Haq, von Rad, O'Connell, et al., 1990).

Later, "outer shelf" or shallow-water lagoonal conditions prevailed, as indicated by the deposition of skeletal grainstones and boundstones alternating rhythmically with calcareous to silty claystones. Hematite staining and red clay associated with the skeletal grainstones and boundstones (microreefs, in part) indicate oxygenated environments, subaerial exposure, minor unconformities, and/or diastems. Detailed petrographic and geochemical studies (Röhl et al., this volume) on the origin of the secondary dolomite, moldic porosities, dissolution effects, and cement analysis suggest much of the diagenetic effects superimposed on these rocks occurred in the meteoric phreatic to meteoric vadose zone early in the history of the limestones.

Littoral conditions existed during the remainder of the Rhaetian. Subtidal mud-supported carbonates, grain-supported high-energy grainstones with oolites, and the presence of algal mats suggest intertidal environments.

\section{Site 764}

The Rhaetian section recovered from Site 764 is approximately 236 m thick (Haq, von Rad, O'Connell, et al., 1990) (Fig. 4). Four Rhaetian carbonate units are present (IV through VII) and consist of calcareous claystones, carbonate mudstones, wackestones, packstones, and grainstones to boundstones. The recovery rate $(17 \%)$ was poor, but the 


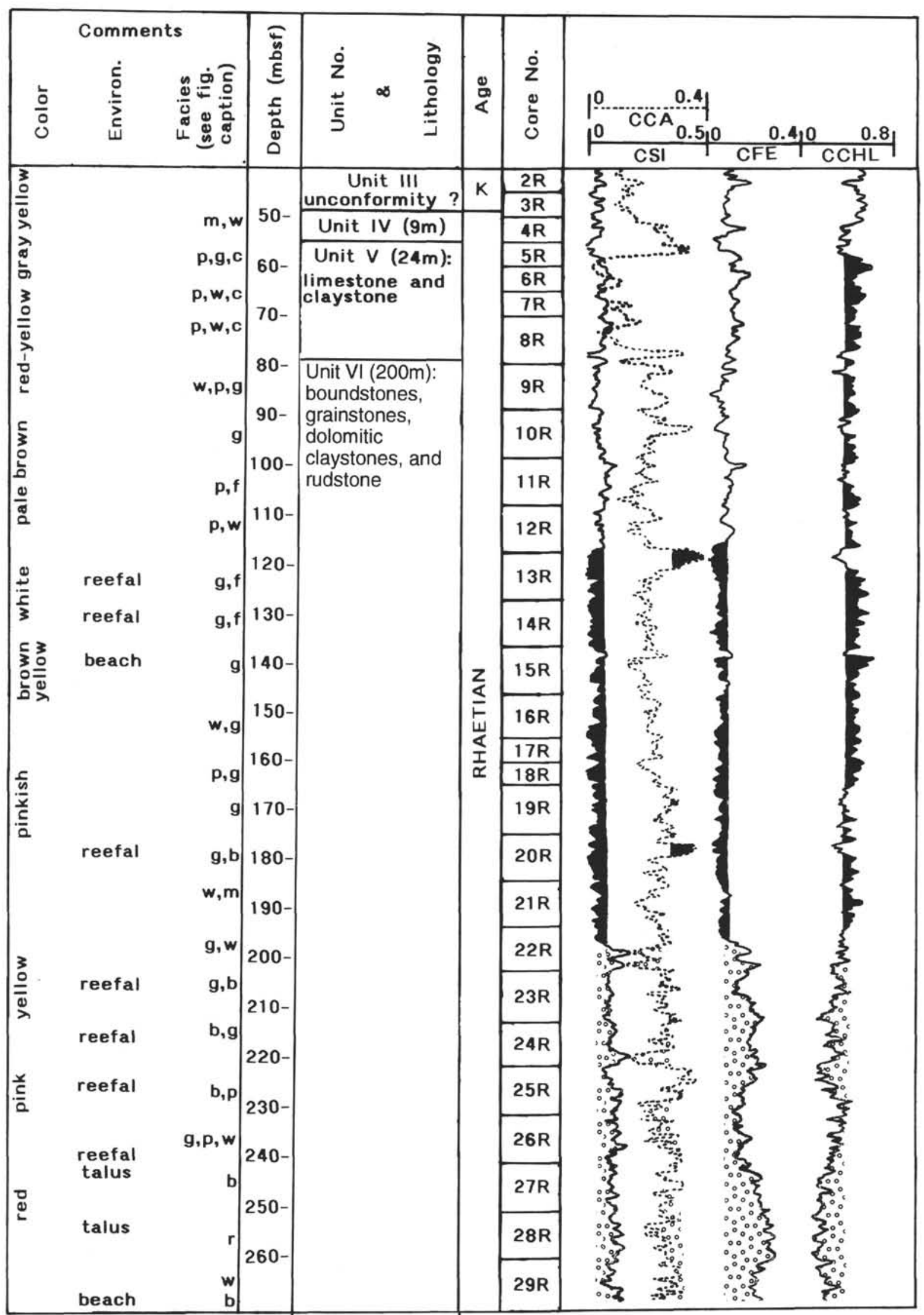

Figure 4. Geochemical logging results from Hole 764B. Presentation as in Figure 3, except claystone (c), boundstone (b), and framestone (f). 
downhole well logs indicate a fairly consistent and uniform signal within each unit, which suggests to us that the recovered samples represent much of the total drilled interval.

Our petrographic descriptions are focused primarily on Unit VI because of its thickness, diagnostic samples, and implications about the regional history and depositional environments that existed during the Late Triassic. Units VII, V, and IV are also discussed, but the lithofacies present within these units are similar to those described at Site 761. A brief summary of these units is included, taken primarily from the shipboard site summary ("Site 764" chapter, Haq, von Rad, O'Connell, et al., 1990).

Continuous seismic profiles (Fig. 2; Williamson et al., 1989) between Sites 761 and 764 along with the biostratigraphic control (Haq, von Rad, O'Connell, et al., 1990) show good correlation between the two sites.

\section{Unit VII (289.14-280.15 mbsf)}

Approximately $9 \mathrm{~m}$ of dark gray carbonate mudstone to wackestone interbedded with clayey carbonate mudstone was drilled. Individual beds range from 5 to $55 \mathrm{~cm}$ in thickness. Boundaries between beds are gradational.

The carbonate mudstones to wackestones are recrystallized and contain $45 \%$ to $50 \%$ clay minerals. Minor quartz and feldspar are present. The interbedded clayey mudstones are also recrystallized. Pelmatozoan fragments are the dominant allochem identified. Other broken fossil debris is present, but the strong bioturbation and postdepositional recrystallization make identification difficult. Diagenesis (differential recrystallization) is a likely cause of the gradational boundaries between beds.

Trace fossils such as Zoophycos sp. and Teichichnus sp. are present, with minor polychaete and halo burrows. The high degree of bioturbation, sediment characteristics, and biostratigraphic evidence (Haq, von Rad, O'Connell, et al., 1990) suggest an open marine to back-reef or lagoonal environment. The boundary between the mudstones and the overlying limestone of Unit VI is conformable.

\section{Unit VI (280.15-79.50 mbsf)}

Unit VI is $200 \mathrm{~m}$ thick and forms the bulk of the Rhaetian carbonate rocks recovered at this site. The limestones recovered $(9.48 \%)$ are well preserved and varied. Calcium carbonate comprises $82 \%$ to $100 \%$ of the samples. The limestones include wackestones, packstones, grainstones, rudstones, and boundstones. Minor carbonate lithofacies include mudstones, laminated claystones, and dolomitic mudstones. Colors range from white, pale brown, light yellow brown, and pink to light red and red.

Fossils are abundant in hand-sized specimens. Many of the fossils are whole. In the boundstones they are large $(>2 \mathrm{~cm})$ and appear to represent the environment where the flora and fauna lived (autochthonous biocoenosis or in-place fossil assemblage). Present are colonial scleractinian corals, sponges, pelecypods, brachiopods, echinoderms, and foraminifers. Scarce green algae, bryozoa, and gastropods are present. Oolites and oncolites are present in several cores containing grainstones and fecal pellets. Large intraclasts are more abundant toward the bottom of the unit.

Megascopically, the matrix is primarily micrite in the finer grained carbonates. Sparite is dominant in the coarser packstones, grainstones, and boundstones.

Texturally, the grainstones, boundstones, and mudstones are highly porous and vuggy. Many vugs are filled with dogtooth calcite, whereas others are stained or infilled with hematite and/or limonite. The rudstones and boundstones characteristically have a vermiform texture indicating coral and calcareous algal growths. Some of these coarse-grained limestones were originally coquinas. Many of the grainstones and rudstones to boundstones are interbedded with hematite and goethite-limonite claystones. The arrangement and composition of the sediments indicate a highly agitated, oxygenated environment. Conditions must have changed episodically to allow the fine-grained iron-rich sediments to accumulate. These iron oxide infillings, stainings, and layers point to periods of subaerial exposure and partial erosion that record either sea-level fluctuations or uplift and subsidence of the Wombat Plateau. The occurrence of these "terra rossas" correlates well with the downhole logging results (see "Logging Results"' section).

The basal portion of the section (Cores 122-764B-30R through 122-764B-27R) contains brecciated rudstones and floatstones interbedded with mudstones, wackestones, and oolitic grainstones. The rudstones contain transported intraclasts with a hematitic carbonate mud matrix and may represent talus deposits that accumulated in front of or behind a reef, or on a ramp. Beneath the rudstones is a graded-bed sequence with coarsegrained bioclasts grading into finer grained oolitic grainstones (Haq, von Rad, O'Connell, et al., 1990). The basal part of the unit contains carbonate mudstones to wackestone. This sequence suggests an increase in mechanical energy conditions upward from the base of the section. Above the mudstoneswackestones lie the oolitic grainstones, which in turn are overlain by rudstones that probably represent reef talus deposits. The remainder of Unit VI contains reef boundstones alternating with intertidal and back-reef grainstones, packstones, and wackestones arranged in five cycles.

Large allochemical grains of corals (PI. 3, Figs. 1 and 3, PI. 4, Fig. 2, and PI. 5, Fig. 3) are present throughout Unit VI. In addition, large algal fragments (dasycladacean algae and others) are present along with large mollusks, sponges, echinoderms, and brachiopods. Within the matrix of the coarsegrained limestones and in the wackestone and packstones, there is abundant shell hash, containing algal fragments, foraminifers, pelmatozoans, mollusks, and ostracodes. Many of the wackestones and packstones are actually single fossil fragments that have been infilled with a micritic matrix (Pl. 4, Fig. 4). Although the thin sections give the appearance of mud support, the rocks are actually grain-supported limestones. Grain-supported textures, such as embayments and interpenetrating contacts are present locally (PI. 5, Figs. 1 and 4).

Many of the fossil allochems have micritic envelopes suggesting that much of the micrite between grains is the result of boring algae and fungi (Pl. 4, Fig. 3). Evidence of neomorphism is present in all of the thin sections. Ghost structures of fossil grains and patchy zones of micrite floating in microspar (PI. 4, Fig. 3, and Pl. 5, Fig. 2) show partial to almost complete transformation of the original allochemical grains to neomorphic sparite. Echinoderms have syntaxial overgrowths and foraminifers show recrystallization and inversion (PI. 5, Fig. 1). In many cases, internal structures of the fossils have been obliterated.

Secondary dolomite is found throughout. Excellent zoned rhombohedral are preserved, many showing ghost nuclei (PI. 3, Fig. 1, and Pl. 4, Fig. 1).

Vuggy or moldic porosity is commonly observed (Pl. 3, Figs. 2 and 4). Many open pore spaces are present but most of the original pores have been infilled by iron oxide or are filled by calcite cement.

Unit $V$ (Hole 764A, 69.00-58.32 mbsf; Hole 764B, 79.50$55.90 \mathrm{mbsf}$

Unit $\mathrm{V}$, averaging $16 \mathrm{~m}$ in thickness, is composed of dark gray calcareous claystones alternating with recrystallized 
clayey peloidal packstones to wackestones. The claystones at the top and bottom of the unit have approximately $29 \%$ calcium carbonate, whereas the recrystallized limestones have an average of $88 \%$ calcium carbonate.

The calcareous claystones were highly disrupted by drilling. Minor amounts of quartz, foraminifers, and nannofossils are present together with recrystallized calcium carbonate grains. The recrystallized clayey wackestones to packstones are pelleted and bioturbated. Chrondrites sp. and Callianassalike burrows are present in thin section. The packstones to wackestones are locally laminated and have iron oxide laminae.

An open marine to shallow-water, below wave base depositional environment is suggested because of the fine-grained mud-supported sediments and the presence of foraminifers, nannofossils, and radiolarians ("Biostratigraphy" section, "Site 764" chapter, Haq, von Rad, O'Connell, et al., 1990).

Unit IV (Hole 764A, 58.32-49.56 mbsf; Hole 764B, 55.90$47.05 \mathrm{mbsf}$ )

Unit IV is approximately $8.8 \mathrm{~m}$ thick and contains carbonate mudstones, wackestones, and peloidal packstones to grainstones. Core recovery was $30 \%$. Fossil abundance in hand specimens varies from moderate to abundant. The fossils consist primarily of mollusk and echinoderm fragments and foraminifers (especially Triasina $\mathrm{sp}$.). Whole fossils are preserved in the finer grained wackestones. Secondary dolomite is associated with neomorphic sparite and shows evidence of recrystallization in thin sections of packstones and grainstones (see "Unit VI").

Minor graded bedding is present, consisting of grainstones fining upward into wackestones and then mudstones. Hematite- and limonite-stained allochems and laminations are present. The laminations are composed of fine-grained carbonate muds and iron oxide (hydroxide) and appear to be postdepositional in origin. Minor black manganese oxide zones and stringers are present and appear to replace allochemical grains and infilling burrows.

The depositional setting for the Unit IV limestones is a shallow-water, well-oxygenated marine environment of quiet to moderate mechanical energy. Episodically, broken and whole fossil allochems were transported into this environment, where they were deposited and subsequently oxidized.

\section{LOGGING RESULTS}

The results of geochemical logs of the Rhaetian sediments at Sites 761 and 764 are presented in Figures 3 and 4 . The original traces of the logs are presented with no smoothing.

The rocks recovered from Site 761 represent upwardshoaling neritic to subtidal, or possibly lagoonal, sediments (wackestones), whereas those recovered from Site 764 are primarily reefal in origin (i.e., grainstones-boundstones, with several possible periods of subaerial exposure). However, both Sites 761 and 764 show similar geochemical logs that appear to be independent of the dominant lithology and depositional setting. The Rhaetian rocks at Site 761 can be divided into two geochemical units, and those at Site 764 can be divided into three. In the section at Site 761, the lower 80 $\mathrm{m}$ is predominantly calcareous claystones and interbedded limestones and the upper $70 \mathrm{~m}$ is mainly neritic limestone. The section recovered at Site 764 contains a 70 -m-thick lower unit of reefal boundstone, rudstone, and grainstone. Above this lies $60 \mathrm{~m}$ of grainstone to wackestone. Overlying this is a 60 -m-thick unit of wackestone, packstone, and claystone.

The basal section at both sites ( 420 to 340 mbsf at Site 761 and 270 to 200 mbsf at Site 764) (Figs. 3 and 4) is characterized by higher silicon and iron and lower calcium and chloride concentrations than the overlying interval. The higher iron and silicon content is most likely related to a higher clay content in the predominantly carbonate rocks. The top of this interval in both sections is marked by yellow to yellow-brown limonite-stained rocks and may represent an unconformity, a hiatus, or at least highly oxidized environments. The chloride ion concentration is relatively low within this interval, which is an indication that the salinity of the pore waters is low. The lower salinity may be a consequence of fresh or brackish water sediment introduction into the area (which correlates well with increased clay), possible periods of subaerial exposure, or sea-level stillstands. Meteoric water migrating through the vadose and phreatic zones could reduce the salinity of the formation waters and also produce the vuggy or moldic porosities that are present (see Röhl et al., this volume, for a discussion of limestone cements). At Site 764 this lowermost interval correlates fairly well with the occurrence of reddish brown to red hematite-stained and clay-filled pores in limestones of reefal origin. Slight changes in sea level would expose the reef to subaerial erosion-creating conditions conducive to forming the classic terra rossa terrain (Esteban and Klappa, 1983). In the bottom interval at Site 761, subaerial erosional features are not present and the suggested environment of deposition is in a slightly deeper water, lower energy zone than the overlying interval. The irregular signature of the silicon, calcium, and iron concentrations and the petrographic analyses suggest the introduction of clay minerals in pulses or cycles into a dominantly carbonate environment. This is possibly due to storms, flooding river waters, or penecontemporaneous deltaic systems located to the south and east. At Site 761 more clayey material is found between 426 and 420 mbsf, at 400 mbsf, and between 385 and 355 mbsf (Fig. 3). Site 764 has clayey zones at 238, 220, and 200 mbsf (Fig. 4), but they are not as extensive. It is also possible that a lowered sea level allowed for greater continental runoff that would extend clastic sedimentation farther offshore into deeper environments. Thus, both mechanisms may have been present during this part of the Rhaetian.

From approximately 340 to $275 \mathrm{mbsf}$ at Site 761 and from 200 to 115 mbsf at Site 764 (Figs. 3 and 4) the geochemical logs have relatively low silicon and iron concentrations and high calcium and chloride content. Less clay was introduced into the environment and a higher salinity (normal marine) appears to have been present. The neritic limestones at Site 761 (Unit IV) indicate that carbonate deposition was fluctuating with minor clay mineral input. A fairly high-energy environment, as indicated by oolites and grain-supported limestones toward the top of Unit IV (Fig. 3), suggests either carbonate buildup equal to or exceeded by subsidence, slow sea-level drop, tectonic uplift, or some combination thereof. Similarly, the geochemical logs at Site 764 show a fairly consistent suite of traces. The petrography indicates that the sediments were deposited in a dominantly high-energy carbonate environment. Reef growth appears to have kept pace with sea-level rise, subsidence, and/or tectonism. The vuggy and moldic textures within the boundstones and grainstones indicate that a frame-supported reef environment existed. The lack of terra rossa indicates that an active reef with less subaerial exposure existed during this interval.

A third geochemical interval (approximately 115 to 50 mbsf) is present at Site 764 . This unit includes the upper portion of lithologic Unit VI (packstone, wackestone, and grainstone), Units V and IV (packstone, wackestone, and claystone), and Unit IV (mudstone to wackestone). The interval has slightly higher silicon and iron than the underlying unit and a highly variable calcium trace. The chloride concentration is fairly consistent and we interpret this as indicating 
that relatively normal marine conditions prevailed and were preserved within the pore waters. The higher iron and silicon is attributed to increased clay content, which is supported by the petrologic studies. Two yellow to reddish yellow oxidized zones are present at approximately 75 and 50 mbsf (Fig. 4). The lowermost oxidized zone correlates with a sudden drop in calcium and may represent a hiatus or unconformity. The upper limonitic zone also occurs in a low-calcium zone that is approximately $10 \mathrm{~m}$ above a sharp increase in calcium. Drilling disturbance is reported in this interval. The upper surface of Unit IV (Rhaetian) is unconformably overlain by Unit III (upper Campanian) chalks. This boundary marks the major angular unconformity observed on seismic records (Fig. 2) and represents subaerial exposure and erosion during the Jurassic followed by final submergence of the Wombat Plateau.

It appears that this upper geochemical interval (115 to 50 mbsf) represents a slightly deeper water, moderate energy, carbonate environment that periodically received clastic sediments. No boundstones or framestones suggestive of active reef growth were observed. Either the active reef environment prevalent in the underlying unit could not keep pace with sea-level rise, subsidence, or tectonism, or oceanographic and climatic conditions changed, preventing an active reef community from existing. Alternatively, subaerial exposure, erosion, and chemical leaching during the Jurassic could have geochemically altered the underlying strata.

\section{DISCUSSION}

The major advantage of participation on an ODP leg is the bringing together of many scientists of different disciplines to focus on a common scientific objective. Complementary to the petrologic, geochemical, and well log data are the regional seismic data and interpretations. Williamson et al. (1989) have presented structural and tectonic interpretations based on regional seismic data and the Leg 122 cores obtained from the Wombat Plateau (Fig. 2). In particular, the reef drilled at Site 764 is not unique to the Wombat Plateau, but many of the underlying seismic "pull-up" structures and zones of discontinuous reflections (reflection-free in places) can be used to identify other Rhaetian reef rocks that fringe the outer edge of the Wombat Plateau (Fig. 5). Associated with many of these reef pull-ups are faults, upon which the unfaulted reef sits on the upthrown side (Fig. 6). The position of the reef appears to be fault controlled and the faults must be pre-Rhaetian in age. The velocity pull-up zones suggest that the velocity of the reef rocks is on the average higher than that of the alternating carbonate and marl layers that surround the reef (Williamson et al., 1989). Using this as a standard along with downlapping seismic facies, reef detrital wedges appear to extend laterally away from the reef for 1 to $2 \mathrm{~km}$ locally.

Williamson et al. (1989) also observed traceable seismic horizons that pass with reduced amplitude through the reef. The seismic horizons correlate with a number of regional unconformities. Our petrologic observations (particularly the oxidized zones) and the geochemical log interpretations at Sites 761 and 764 correlate nicely with the seismic horizons. At Site 764 these unconformities may indicate breaks in reef growth separated by periods of erosion or nondeposition. This, in turn, indicates multiple tectonic, eustatic, or subsidence changes that occurred within a 5-m.y. interval.

One of the major purposes of Leg 122 was to test and refine the worldwide sea-level eustacy curves (Haq et al., 1987, 1988). Large-scale sea-level fall (encompassing a short-term sea-level rise peaking at $211.5 \mathrm{~m} . \mathrm{y}$.) characterizes the Rhaetian. There is no doubt that changes in sea-level are recorded within the rocks recovered from all of the sites drilled on Leg
122. However, the cause of the fluctuations is a more fundamental question and is a topic of debate.

Penecontemporaneous depositional environments found elsewhere in the world show similar sedimentation patterns. For example, in the Sverdrup Basin, a major depocenter in the Canadian Arctic Archipelago, marine Triassic sedimentary rocks are widespread and up to $4000 \mathrm{~m}$ thick. These rocks are thick progradational wedges of deltaic and marine strata alternating with thin transgressive-regressive clastic units. Subaerial unconformities cap progradational wedges and submarine unconformities form cycle boundaries. Nine Triassic transgressive-regressive cycles are recognized and are interpreted to be the result of eustatic sea-level change, thermal subsidence, increase and decrease in sediment supply, and load subsidence. The youngest of the transgressive-regressive cycles indicates a rapid sea-level rise coinciding with a major transgression that continued from the earliest Rhaetian to the earliest Jurassic. Progradation occurred under conditions of slow eustatic sea-level rise, standstill, and fall (Embry, 1988). The long duration of sea-level cycles (approximately 5 m.y.) and the apparent lack of Triassic glacial deposits indicate that the cycles have a tectono-eustatic origin. Sea-level changes are caused by the interplay of changes in the volume of the oceans, increased seafloor spreading, and oceanic volcanism. Sea-level fall could occur when seafloor spreading and volcanism are subdued and the ocean basins enlarged due to thermal subsidence. Larger scale sea-level variation (approximately $60 \mathrm{~m} . \mathrm{y}$.) can be attributed to a pulsation tectonic model (Sheridan, 1986), which also may affect the frequency of magnetic reversals. These large- and medium-scale sealevel falls can be recognized at the level of seismic stratigraphic resolution, but detailed well log and outcrop observations are needed to resolve minor sea-level variations (Haq et al., 1988).

Kendall and Lerche (1988) proposed that sea-level curves represent the net change due to the interplay of tectonic subsidence and eustatic sea-level rise and fall. Sarg (1988) concluded that changes in carbonate productivity, facies distribution, and stratal patterns on carbonate platforms are controlled by relative changes in sea level, which is the net change of eustacy and subsidence. Depositional setting (basin architecture) and climate also exert a strong control. Abrupt breaks in sea-floor slope, such as at the edge of isolated horst blocks or along rifted basin margins, may localize reefs or carbonate-sand shoals (Sarg, 1988). Unrestricted basins with normal, well-circulated marine waters provide a favorable habitat for a more cosmopolitan biota with a growth potential different from that of a restricted basin. Basins with an elevated salinity or deficient oxygen have a specialized or reduced biota.

Climate is an important control on carbonate facies development (e.g., arid vs. humid, high rainfall vs. low rainfall) and on the extent of early postdepositional diagenesis associated with the exposure of the carbonate unit during times of falling or lowstands in sea level.

Tethyan carbonates, however, were short-lived depositional systems that were initiated, developed, and then perished in a short geologic time span (Bosellini, 1989). They were resurrected in a tectonically active area where rifting, drifting, transtension, transgression, and collision occurred. Bosellini (1989) further stated that the lack of Tethyan ramps and the common occurrences of faulted boundaries and megabreccia wedges suggest tectonics as a primary control whereas eustacy and sea-level oscillations are only a secondary overprint. During rifting, these Tethyan platforms (plateaus) were drowned or underwent tectonic subsidence with some carbonate environments surviving. The shedding of ooid sands 

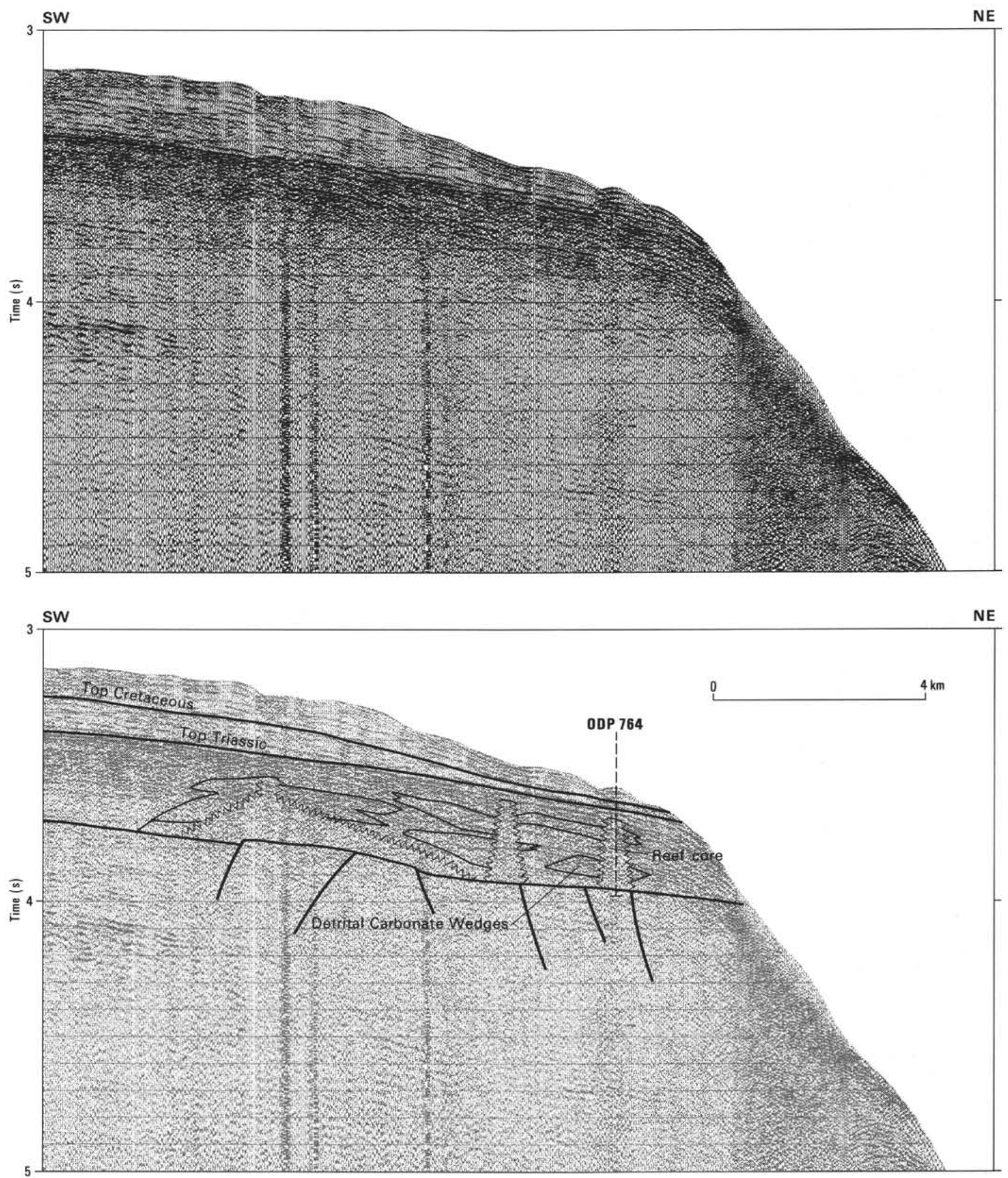

Figure 5. ODP line 122-6, Site 764. Upper seismic record, uninterpreted; lower seismic record, interpreted. Notice seismic pull-up, lateral extent of carbonate wedges, and pre-Rhaetian faults (taken from Williamson et al., 1989). 

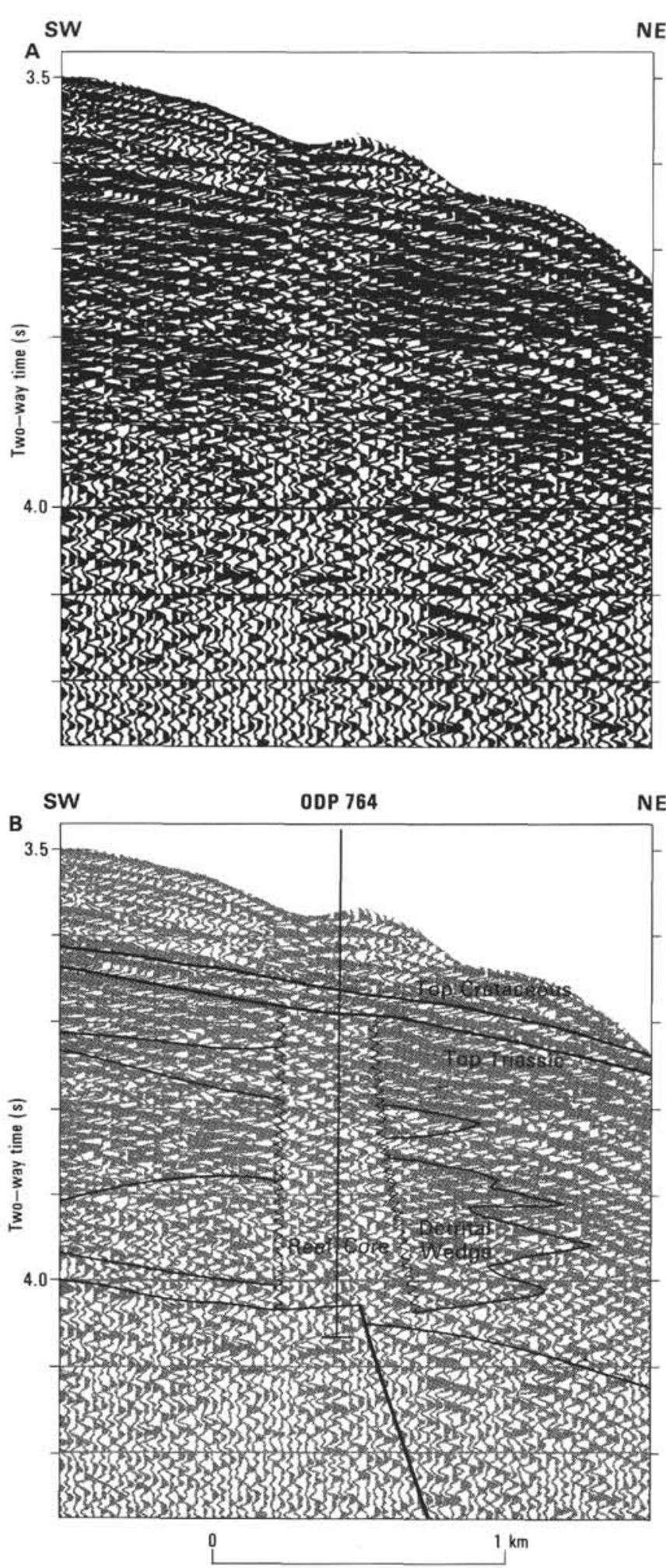

Figure 6. Detailed interpretation of reef at Site 764 on ODP line 122-113. A. Uninterpreted. B. Interpreted. The reef complex appears to be fault controlled (after Williamson et al., 1989). during highstands and subaerial exposure with karst topography and bauxite development during lowstands were typical events in the Tethys during the Jurassic through the middle Cretaceous. Conversely, Röhl et al. (this volume) and Dumont (this volume) suggested that Tethyan ramps are a possibility and eustacy is the dominant controlling force on carbonate accumulation. Goldhammer and Harris (1988) concluded that the Middle Triassic dolomites of northern Italy were controlled primarily by eustacy, in which both the short-term and long-term fluctuations are related to Milankovitch oscillations.

During the Triassic on the Wombat Plateau and in the remaining Tethys, extension tectonics and rifting had begun. Post-Carnian faults are shown in Figure 5. Pinnacle-shaped fringing reefs, apparently fault controlled, were present on the margins of the plateau (Fig. 6). Periods of subaerial exposure and erosion and/or stillstands are recorded within the Rhaetian at Sites 761 and 764 . Nearby to the west, volcanism occurred at about the Triassic/Jurassic boundary (von Rad and Exon, 1983; Bradshaw et al., 1988). Master faults (Fig. 2) indicate that faulting and tectonism continued through the Cretaceous. Tilting and immersion of the plateau occurred during the Jurassic (Röhl et al., this volume). Jurassic strata are missing from the plateau, indicating a long period (approximately $60 \mathrm{~m} . \mathrm{y}$.) of tectonic uplift and erosion or nondeposition. Finally, the Wombat Plateau subsided and drifted into a pelagic realm. We suggest that tectonic activity was present throughout the Mesozoic and tectonism is the controlling force for the origin of the Wombat "horst" and distribution of the sedimentary rocks found on the plateau.

Imposed on this major tectonic theme are minor fluctuations observed in the sedimentary record that may be caused by sea-level changes in conjunction with tectonic activity and subsidence, producing a "yo-yo" effect between the crustal fragments and sea level. Röhl et al. (this volume) and Dumont (this volume) suggested that there are definite periods in the Rhaetian where the eustatic signal can be identified on both the Wombat Plateau and in the western Tethys.

Based on the evidence presented, local tectonic changes are primarily responsible for the formation and evolution of the Wombat Plateau in addition to the distribution of sedimentary rocks and sediments on the plateau. Eustatic signals may be present but are masked by the tectonic overprint. Therefore, this area is unsuitable as a model site to test worldwide sea-level changes during the Mesozoic (Rhaetian).

\section{CONCLUSIONS}

During the Rhaetian, carbonate depositional environments existed on the Wombat Plateau. On the margins of the plateau, extensive reefal communities developed (Site 764). This is supported by seismic interpretation that can be correlated to the recovered reef limestones. The presence of Rhaetian reefs represents the first discovery of reef environments off the Northwest Shelf of Australia in a vast and relatively unexplored area.

Closer to mainland Australia, lagoonal-intertidal to slightly deeper water, low- to moderate-energy carbonate environments (wackestones, mudstones) existed (Site 761). These environments were periodically inundated by siliciclastic sediments from floods or nearby active deltaic systems.

Geochemical well logs correlate well with the petrography and seismic records. Several unconformities representing periods of subaerial exposure, sea-level fluctuations and stillstands, or nondeposition are present within the cores and are recorded on the geochemical logs. The unconformities correlate well with reduced-amplitude seismic horizons that pass through the reef environment. 
The limestones, including the reefs, are porous. Lowvelocity zones on the seismic records correlate with iron enrichment and suggest subaerial exposure. If this correlation can be substantiated with additional exploration then implications for the widespread development of porosity are enormous. This should provide stimulation to petroleum geologists when future exploration in deep water becomes more feasible.

Tectonism is the dominant force controlling the distribution of sedimentary facies, sea-level fluctuations, and development of the Wombat Plateau. Minor eustatic changes are recorded in the rocks (Dumont, this volume; Röhl et al., this volume) but their signals are hard to recognize as a result of the masking effect of tectonism, climate, and basin geometry.

\section{ACKNOWLEDGMENTS}

We are grateful for the opportunity to have participated on Leg 122 of the Ocean Drilling Program. The original manuscript was reviewed by A. N. Yeates, Pamela Gore, and Ulrich von Rad. Their criticisms and corrections are appreciated. We also thank the Australian Bureau of Mineral Resources for providing copies of the seismic-reflection records. Support funds for this study were provided by the Joint Oceanographic Institutions U.S. Science Support Program. Mary Amelotte kindly typed and edited all versions of the manuscript. The original drafting was done by Sean Wilson.

\section{REFERENCES}

Bathurst, R.G.C., 1966. Boring algae, micrite envelopes and lithification of molluscan biosparites. Geol. J., 5:15-32.

1971. Carbonate Sediments and Their Diagenesis: Amsterdam (Elsevier).

Borehole Research Group, 1989. Wireline Logging Manual (vol. 1): Palisades, NY (Lamont-Doherty Geological Observatory, Columbia Univ.).

Bosellini, A., 1989. Dynamics of Tethyan carbonate platforms. In Crevello, P. D., Wilson, J. L., Sarg, F., and Read, J. F. (Eds.), Controls on Carbonate Platform and Basin Development. Spec. Publ.-Soc. Econ. Paleontol. Mineral., 44:3-14.

Bradshaw, M. T., Yeates, A. N., Beynon, R. M., Brakel, A. T., Langford, R. P., Totterdell, J. M., and Yeung, M., 1988. Paleogeographic evolution of the North West Region. In Purcell, P. G., and Purcell, R. R. (Eds.), The North West Shelf, Australia: Proc. Pet. Expl. Soc. Aust. Symp., 29-54.

Dunham, R. J., 1962. Classification of carbonate rocks according to depositional texture. In Ham, W. E. (Ed.), Classification of Carbonate Rocks: AAPG Mem., 1:108-121.

Embry, A. F., 1988. Triassic sea-level changes: evidence from the Canadian Arctic Archipelago. In Wilgus, C. K., Hastings, B. S., Kendall, C.G.St.C., Posamentier, H. W., Ross, C. A., and Van Wagoner, J. C. (Eds.), Sea-Level Changes: An Integrated Approach. Spec. Publ.-Soc. Econ. Paleontol. Mineral., 42:249-260.

Esteban, M., and Klappa, C. F., 1983. Subaerial exposure environment. In Scholle, P. A., Bebout, D. G., and Moore, C. H. (Eds.), Carbonate Depositional Environments. AAPG Mem., 33:1-54.

Exon, N. F., and Willcox, J. B., 1978. Geology and petroleum potential of the Exmouth Plateau area off Western Australia. AAPG Bull., 62:40-72.

1980. The Exmouth Plateau: stratigraphy, structure and petroleum potential. Bull. Bur. Miner. Resour. Geol. Geophys. Aust., 199.

Exon, N. F., and Williamson, P. E., 1988. Preliminary post-cruise report, Rig Seismic research cruises 7 and 8: sedimentary basin framework of the northern and western Exmouth Plateau. Bur. Min. Resour. Aust. Rec., 1988/30.

Fairbridge, R. W., 1982. The fracturing of Gondwanaland. In Scrutton, R. A., and Talwani, M. (Eds.), The Ocean Floor: New York (Wiley), 229-235.

Falvey, D. A., and Veevers, J. J., 1974. Physiography of the Exmouth and Scott Plateau, Western Australia, and adjacent northeast Wharton Basin. Mar. Geol., 17:21-59.
Flügel, E., 1982. Microfacies Analysis of Limestones: New York (Springer-Verlag).

Folk, R. L., 1962. Spectral subdivision of limestone types. In Ham, W. E. (Ed.), Classification of Carbonate Rocks. AAPG Mem., $1: 62-68$.

Goldhammer, R. K., and Harris, M. T., 1988. Eustatic controls on the stratigraphy and geometry of the Latemar Buildup (Middle Triassic), the dolomites of northern Italy. In Crevello, P. P., Wilson, J. C., Sarg, J. F., and Read, J. F. (Eds.), Controls on Carbonate Platform and Basin Development, Spec. Publ.-Soc. Econ. Paleontol. Mineral., 44:303-338.

Haq, B. U., Hardenbol, J., and Vail, P. R., 1987. Chronology of fluctuating sea levels since the Triassic. Science, 235:1156-1167. 1988. Mesozoic and Cenozoic chronostratigraphy and eustatic cycles. In Wilgus, C. K., Hastings, B. S., Kendall, C.G.St.C., Posamentier, H. W., Ross, C. A., and Van Wagoner, J. C. (Eds.), Sea-Level Changes: An Integrated Approach. Spec. Publ.-Soc. Econ. Paleontol. Mineral., 42:71-108.

Haq, B. U., von Rad, U., O'Connell, S., et al., 1990. Proc. ODP, Init. Repts., 122: College Station, TX (Ocean Drilling Program).

Kendall, C.G.St.C., and Lerche, I., 1988. The rise and fall of eustacy. In Wilgus, C. K., Hastings, B. S., Kendall, C.G.St.C., Posamentier, H. W., Ross, C. A., and Van Wagoner, J. C. (Eds.), Sea-Level Changes: An Integrated Approach. Spec. Publ.-Soc. Econ. Paleontol. Mineral., 42:3-18.

Leg 123 Shipboard Scientific Party, 1989. The birth of the Indian Ocean. Nature, 337:506-507.

Mutter, J. C., Larson, R. L., and Northwest Australia Study Group, 1989. Extension of the Exmouth Plateau, offshore northwestern Australia: deep seismic reflection/refraction evidence for simple and pure shear mechanisms. Geology, 17:15-18.

Rider, M. H., 1986. The Geological Interpretation of Well Logs: New York (Halsted Press).

Sarg, J. F., 1988. Carbonate sequence stratigraphy. In Wilgus, C. K., Hastings, B. S., Kendall, C.G.St.C., Posamentier, H. W., Ross, C. A., and Van Wagoner, J. C. (Eds.), Sea-Level Changes: An Integrated Approach. Spec. Publ.-Soc. Econ. Paleontol. Mineral., 42:155-181.

Schlanger, S. O., 1964. Petrology of the limestones of Guam. Geol. Surv. Prof. Pap. U.S., 403-D:1-52.

Scholle, P. A., 1979. Aspects of Diagenesis. Spec. Publ.-Soc. Econ. Paleontol. Mineral., 26.

Scholle, P. A., Bebout, D. G., and Moore, C. H. (Eds.), 1983. Carbonate Depositional Environments. AAPG Mem., 33.

Sheridan, R. E., 1986. Pulsation tectonics as the control of North Atlantic paleoceanography. In Summerhayes, C. P. (Ed.), North Atlantic Paleoceanography. Geol. Spec. Publ., 21:255-275.

Veevers, J. J., 1988. Morphotectonics of Australia's northwestern margin: a review. In Purcell, P. G., and Purcell, R. R. (Eds.), The North West Shelf, Australia: Proc. Pet. Expl. Soc. Aust. Symp. 19-27.

Veevers, J. J., and Cotterill, D., 1979. Western margin of Australia: a Mesozoic analogue of the East Africa rift system. Geology, 7:713-717

Veevers, J. J., and Johnstone, M. H., 1974. Comparative stratigraphy and structure of the western Australian margin and the adjacent deep ocean floor. In Veevers, J. J., Heirtzler, J. R., et al., Init. Repts. DSDP, 27: Washington (U.S. Govt. Printing Office), 571585.

von Rad, U., and Exon, N. F., 1983. Mesozoic-Cenozoic sedimentary and volcanic evolution of the starved passive continental margin off northwest Australia. In Watkins, J. S., and Drake, C. L. (Eds.), Studies in Continental Margin Geology: AAPG Mem., 34:253281.

von Rad, U., Thurow, J., Haq, B. U., Gradstein, F., Ludden, J., and ODP Leg 122/123 Shipboard Scientific Parties, 1989. Triassic to Cenozoic evolution of the NW Australian continental margin and the birth of the Indian Ocean (preliminary results of ODP Legs 122 and 123). Geol. Rundsch., 78:1189-1210.

Willcox, J. B., and Exon, N. F., 1976. The regional geology of the Exmouth Plateau. APEA J., 16:1-11.

Williamson, P. E., Exon, N. F., Haq, B. U., von Rad, U., O'Connell, S., and Leg 122 Shipboard Scientific Party, 1989. A Northwest 
Shelf Triassic reef play: results from ODP Leg 122. APEA J., 29:328-344.

Williamson, P. E., and Falvey, D. A., 1988. Preliminary post-cruise report: Rig Seismic research cruises 7 and 8: deep seismic structure of the Exmouth Plateau. BMR Geol. Geophys. Rec., 1988/31.

Yeates, A. N., Bradshaw, M. T., Dickens, J. M., Brakel, A. T., Exon, N. F., Langford, R. P., Mullholland, S. M., Totterdell, J.
M., and Yeung, M., 1986. The Westralian Superbasin: an Australian link with Tethys. In McKenzie, K. G. (Ed.), Shallow Tethys 2: Rotterdam (A. A. Balkema), 199-213.

Date of initial receipt: 7 May 1990

Date of acceptance: 22 February 1991

Ms 122B-143 


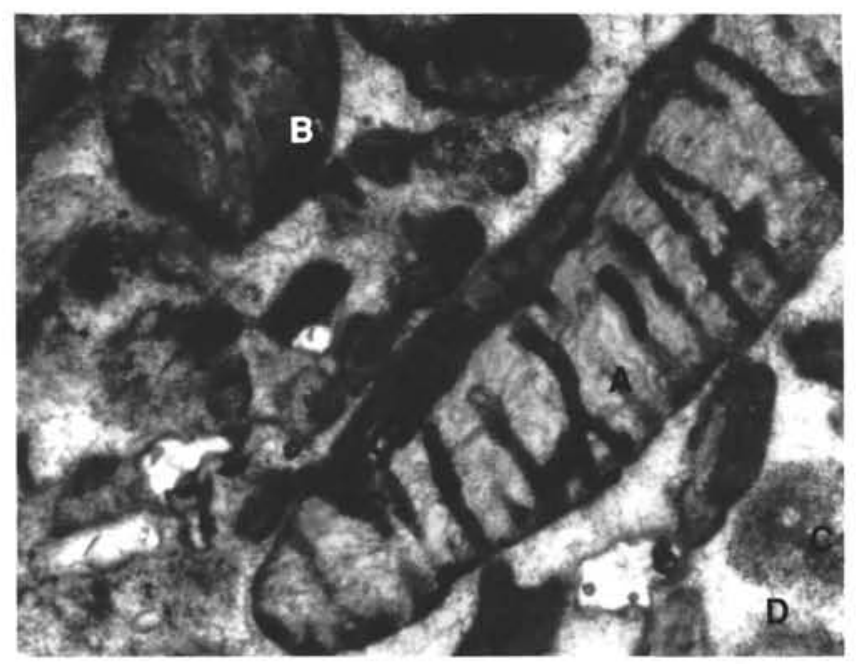

1

$1 \mathrm{~mm}$

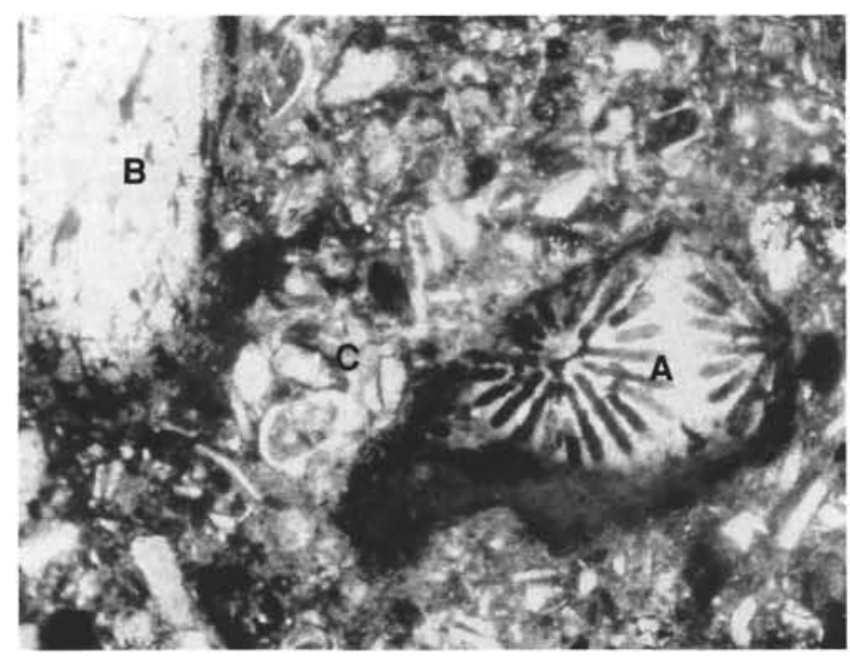

3

$1 \mathrm{~mm}$

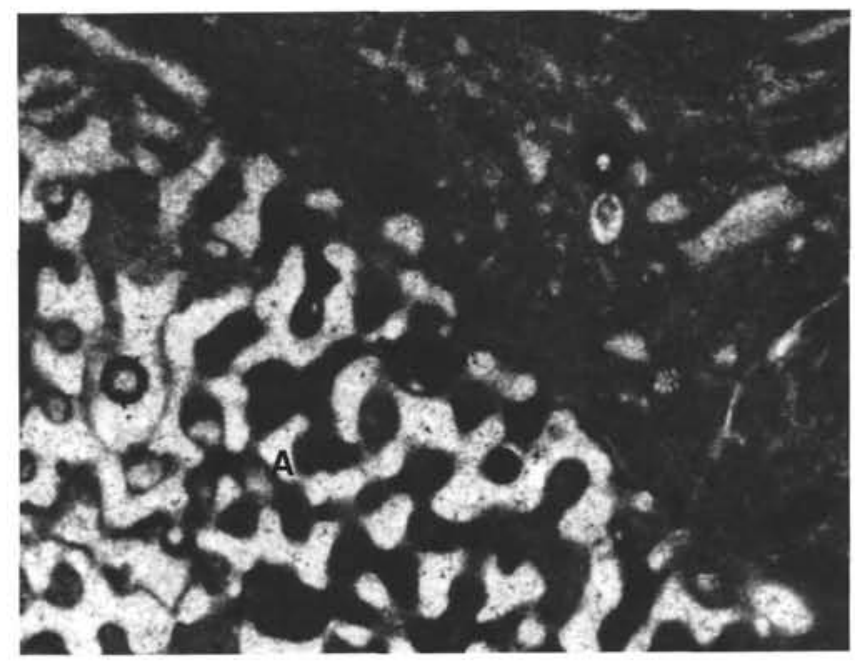

2

$1 \mathrm{~mm}$

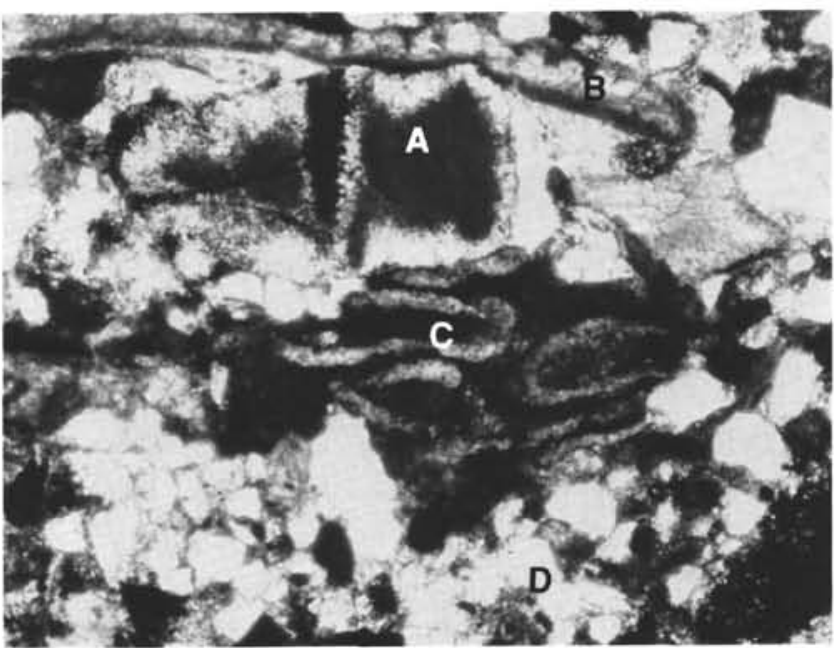

4

$1 \mathrm{~mm}$

Plate 1. Thin-section photomicrographs of Subunits VA and VB lithology, Site 761. 1. Sample 122-761C-28R-1, 40-44 cm, Subunit VA. Mollusk, echinoderm, foraminifer-peloidal grainstone. Micrite-filled borings in mollusk (A). Peloids (B) with micritized coatings. Echinoderm fragment (C) with neomorphic spar (D) between grains in overly close packing network. 2. Sample 122-761C-30R-1, 15-17 cm, Subunit VA. Boundstone: coralline red algae (A) with micritic infillings and shell debris. The aragonitic skeleton of the allochem has been inverted to low-magnesium calcite with well-preserved internal structure. 3. Sample 122-761C-31R-2, 50-52 cm, Subunit VB. Packstone: hematite-stained coral allochem (A) that was inverted to calcite. Large algal fragment (B) and shell debris (C) consisting of pelmatozoans, mollusks, sponge spicules, and benthic foraminifers. 4. Sample 122-761C-32R-CC, 1-5 cm, Subunit VB. Grainstone with abundant quartz and feldspar. Echinoderm (A) with syntaxial overgrowth. Mollusk (B) with micritic infillings and coatings and squashed peloids (C). Bright areas (D) are quartz and feldspar grains. The thin section exhibits faint laminations. 


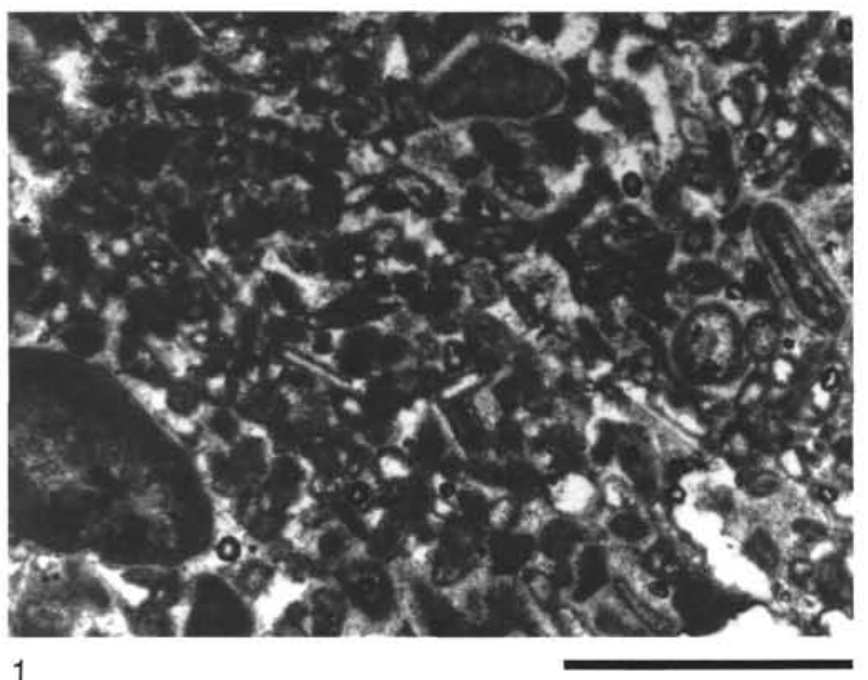

$1 \mathrm{~mm}$

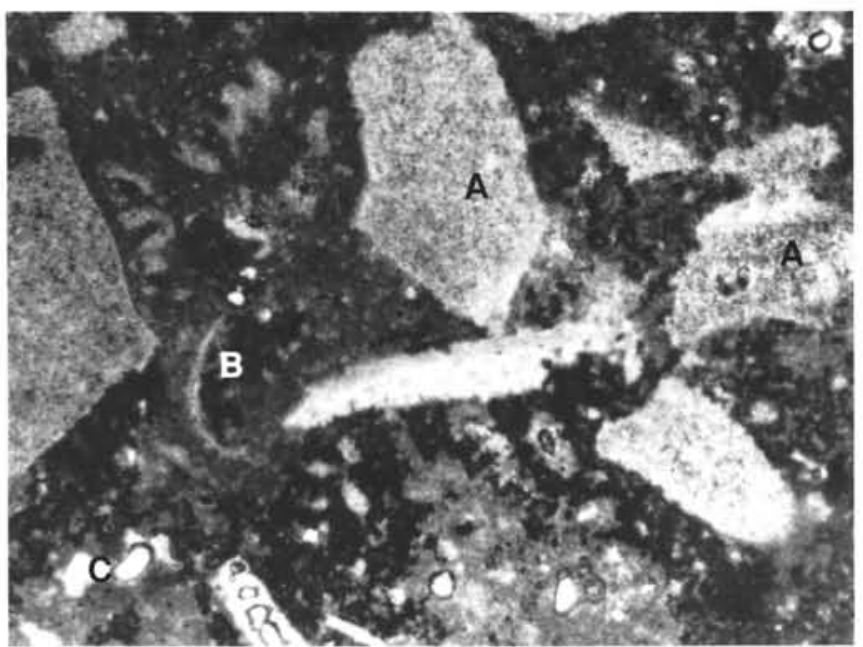

3

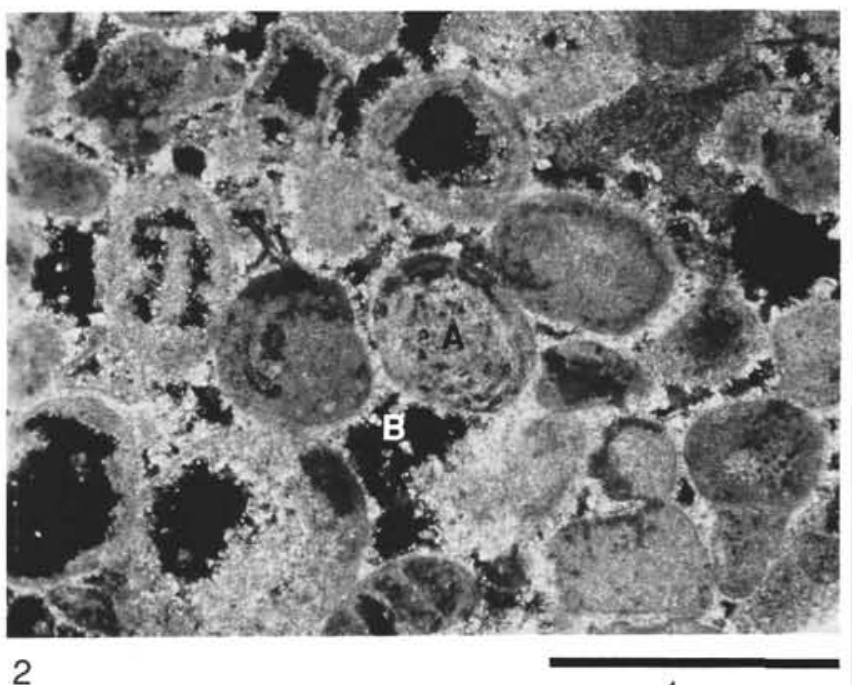

$1 \mathrm{~mm}$

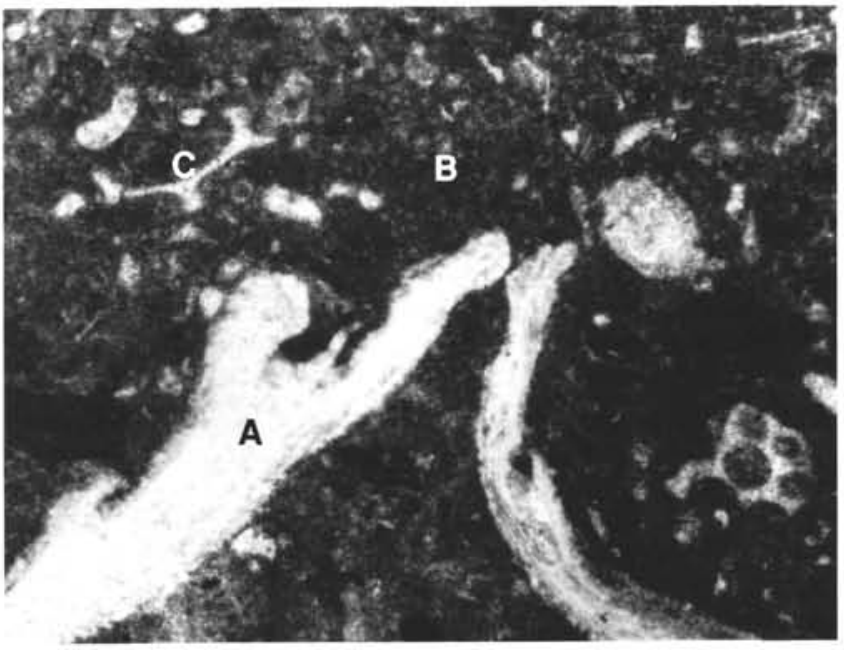

4

$1 \mathrm{~mm}$

Plate 2. Thin-section photomicrographs of Unit IV lithology, Site 761. 1. Sample 122-761C-12R-1, 52-55 cm. General texture of ooid-peloidforaminifer packstone to grainstone of Unit IV. 2. Sample 122-761C-13R-1, 6-9 cm. Ooid-peloid-foraminifer grainstone. Peloidal-appearing foraminifer (Triasina sp.?) (A) with intergranular pore space (B) and pore-filling cements between allochemical grains. Minor iron oxide staining around grains. 3. Sample 122-761C-22R-1, 5-8 cm. Wackestone. Angular echinoderm fragments (A) with syntaxial overgrowths and mollusk debris (B) within a mottled and vuggy micrite matrix. Light areas (C) are voids. 4. Sample 122-761C-22R-1, 25-28 cm. Wackestone. Large mollusk (A) fragment in micrite matrix (B) with shell fragments (C). Note preservation of original wall structure. 


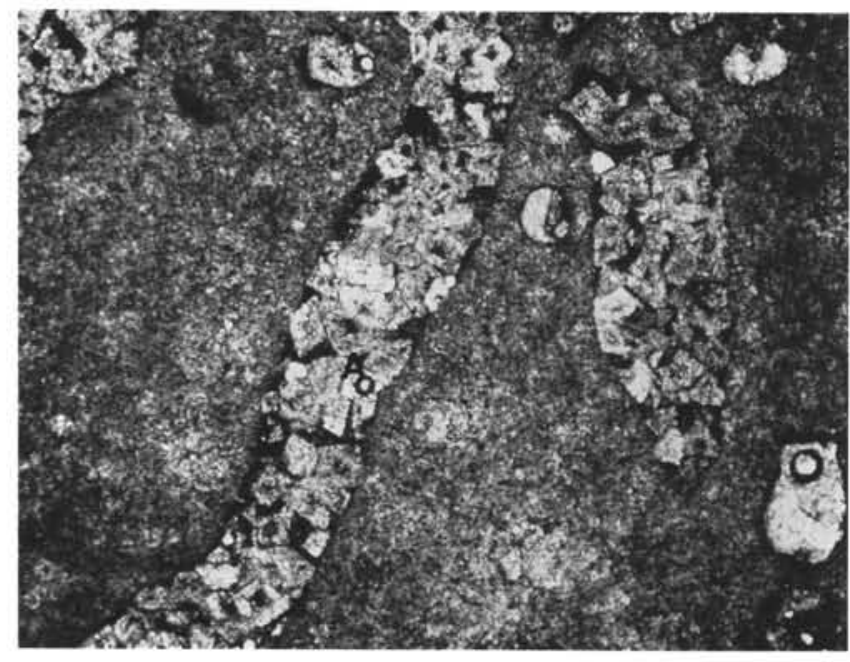

1

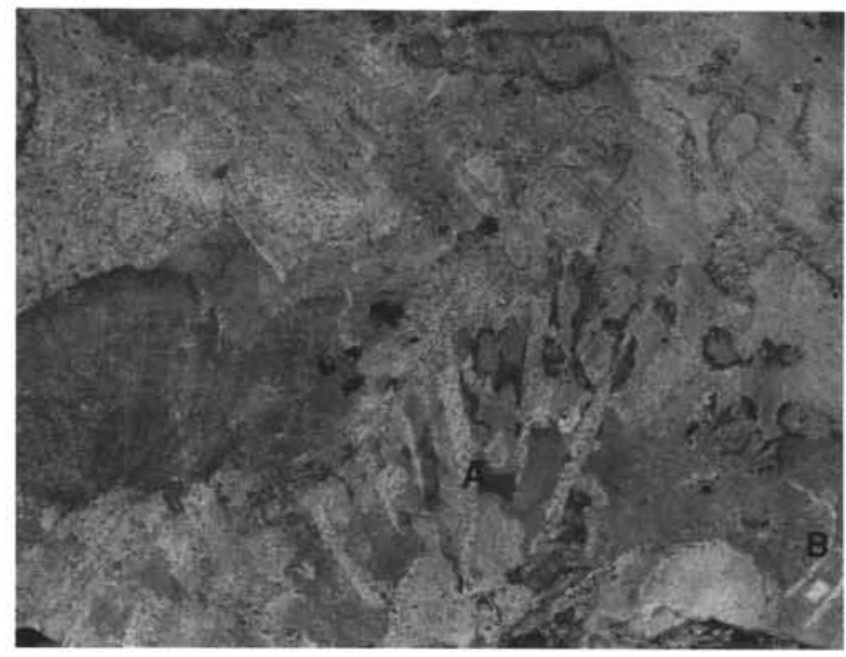

3
$1 \mathrm{~mm}$

$1 \mathrm{~cm}$

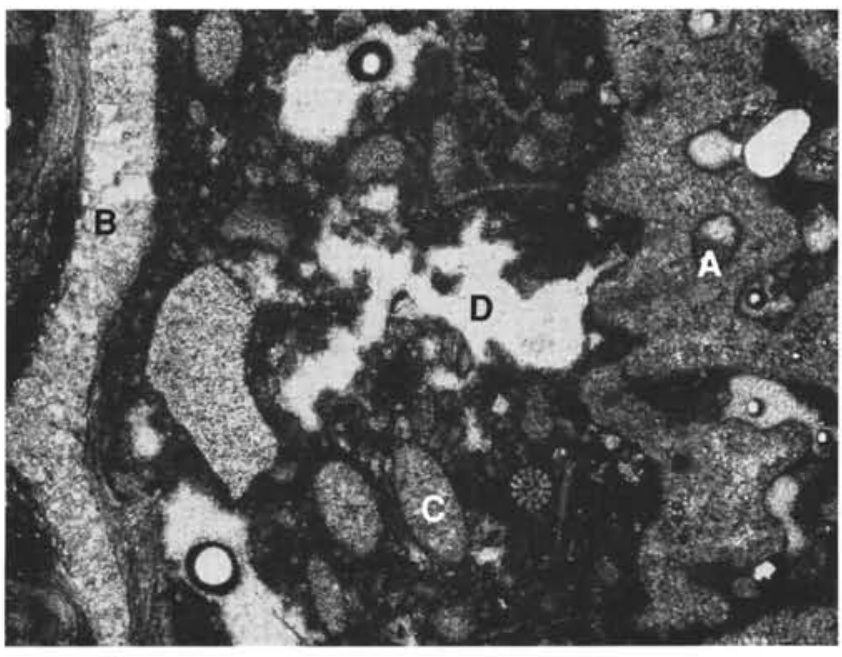

2

$1 \mathrm{~mm}$

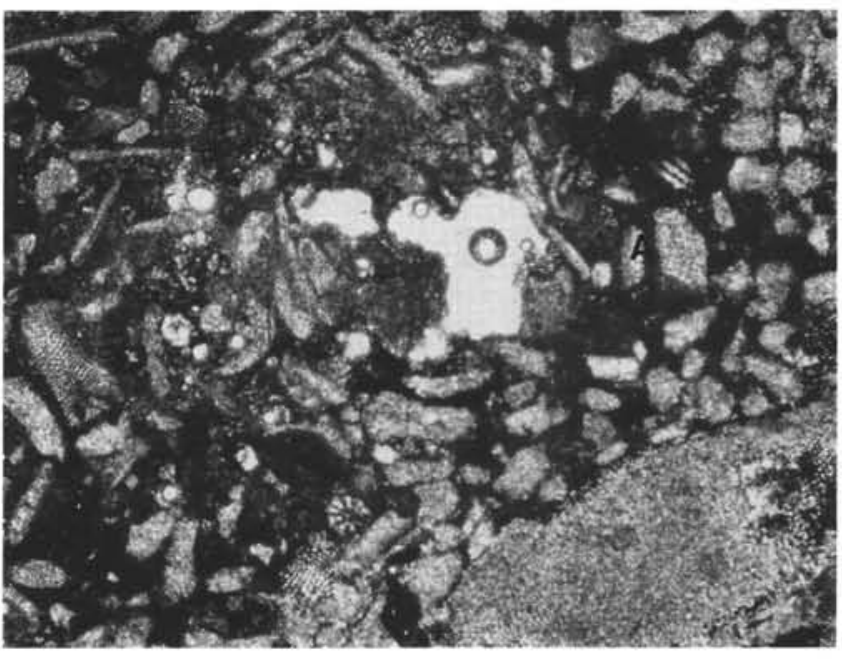

4

$1 \mathrm{~mm}$

Plate 3. Thin-section photomicrographs and core photograph of Unit VI lithology, Site 764. 1. Sample 122-764B-26R-1, 53-55 cm. Coral boundstone. Thin section is a single coral. Secondary zoned dolomite (A) in void space within coral. 2. Sample 122-764B-27R-1, 74-76 cm. Wackestone to coral-algal boundstone. Large algal fragment (A), recrystallized brachiopod (?) (B), peloids (C), and echinoderm fragments with micrite coatings and infillings. Light areas are pore spaces (D). The general appearance of the slide is a laminated texture with iron oxide staining. 3. Sample 122-764B-28R-1, 86-92 cm. Large coral (A) in boundstone with mollusk fragment (B). Matrix is vuggy and recrystallized. 4. Sample 122-764B-28R-3, 113-116 cm. Encrinal packstone interbedded with rudstone. Abundant fossil debris with fine-grained micritic matrix (A). Pink to red in color. Dolomite present. 

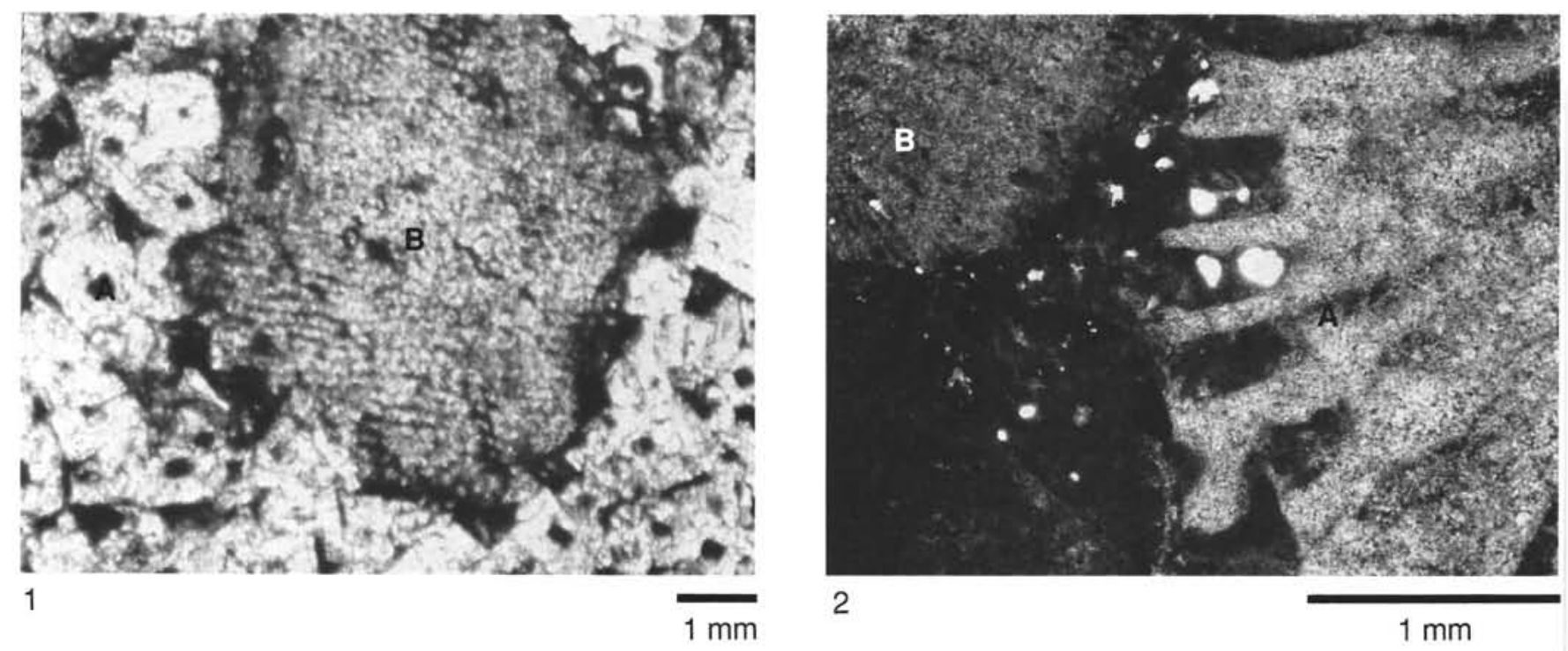

2

$1 \mathrm{~mm}$

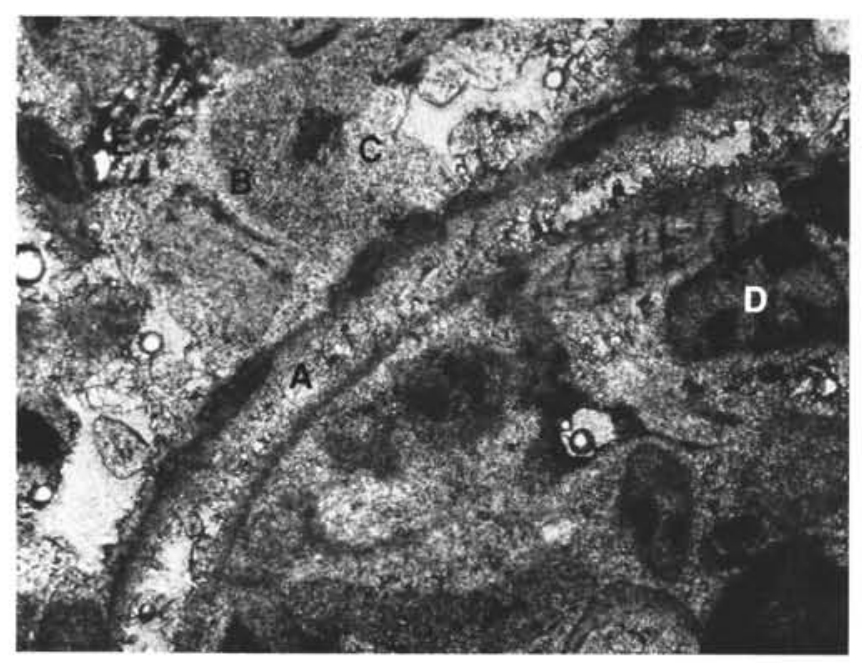

3

$1 \mathrm{~mm}$

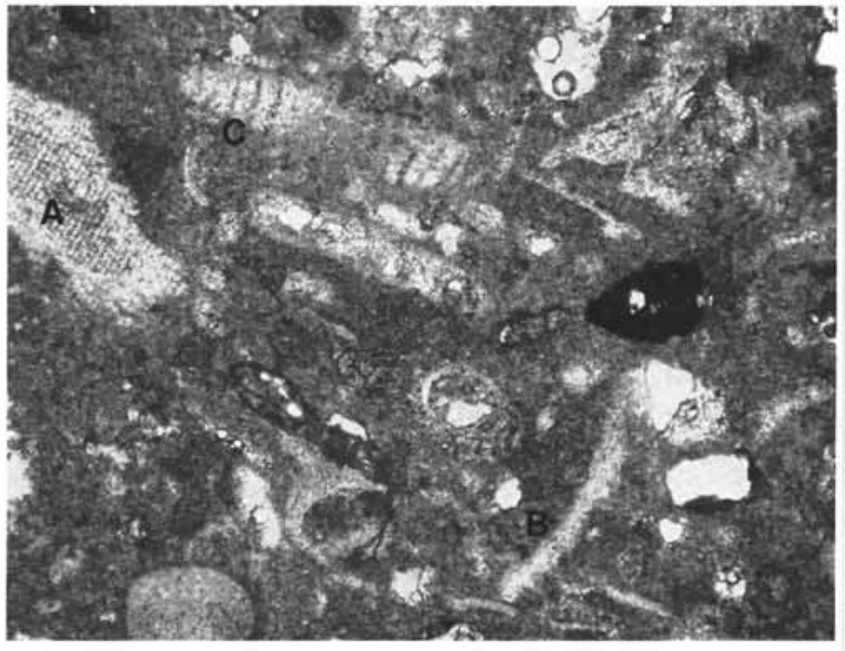

4

$1 \mathrm{~mm}$

Plate 4. Thin-section photomicrographs of Unit VI lithology, Site 764. 1. Sample 122-764B-21R-CC, 26-28 cm. Dolomitized packstone to grainstone. Zoned dolomite (A) surrounding pelmatozoan fragment (B). Note dolomite replacing pelmatozoan fragment. Dark areas between dolomite grains are filled with limonite. 2. Sample 122-764B-25R-1, 14-16 cm. Boundstone to rudstone. Large coral fragment (A) and coralline algae(?) allochem (B) with micrite between allochems. Bright areas on slide are pore spaces producing a vuggy texture. 3. Sample 122-764B-26R-1, 13-16 cm. Grainstone. Large mollusk fragment (A) surrounded by micritic envelope and internal neomorphic sparite. Pelmatozoans (B) with syntaxial overgrowths being dissolved and replaced with pore-filling calcite (C). Algal fragments in areas (D) and (E). Note overly close packing and embayed grains. 4. Sample 122-764B-26R-1, 19-21 cm. Wackestone to packstone within large coral boundstone. Allochemical grains include pelmatozoans (A), mollusk (B), and algae (C). Micrite matrix shows patchy recrystallization and moldic (vuggy) texture. 


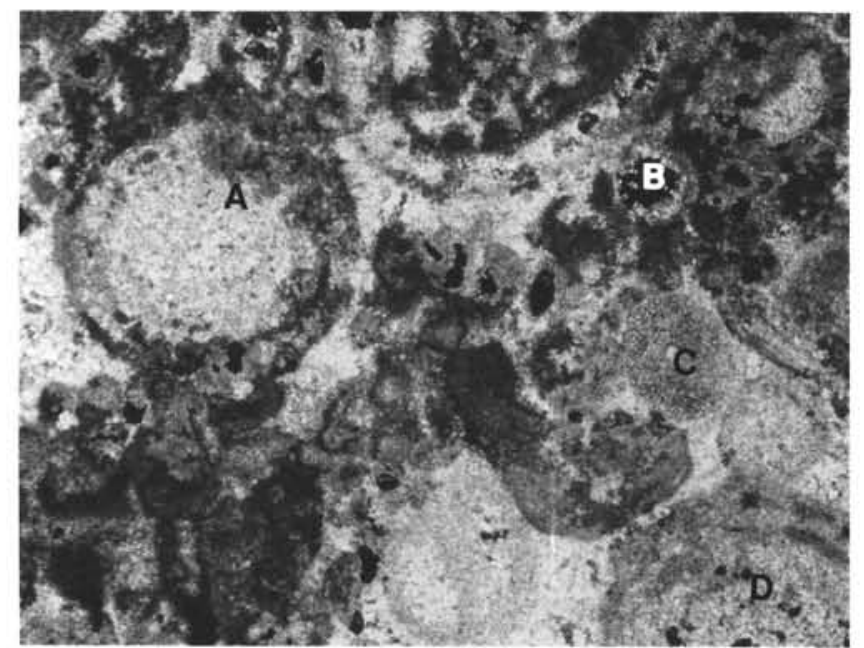

1

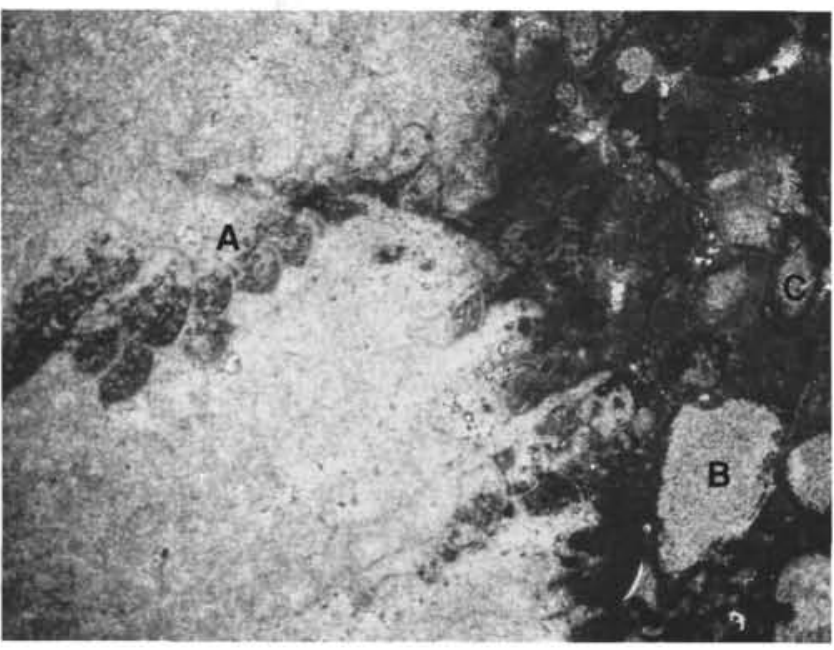

3

$1 \mathrm{~mm}$

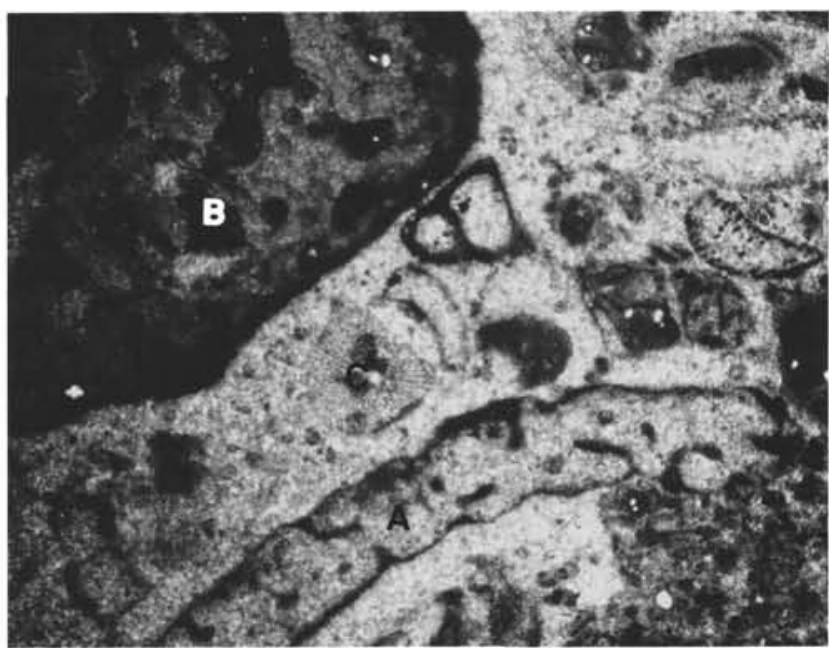

2

$1 \mathrm{~mm}$

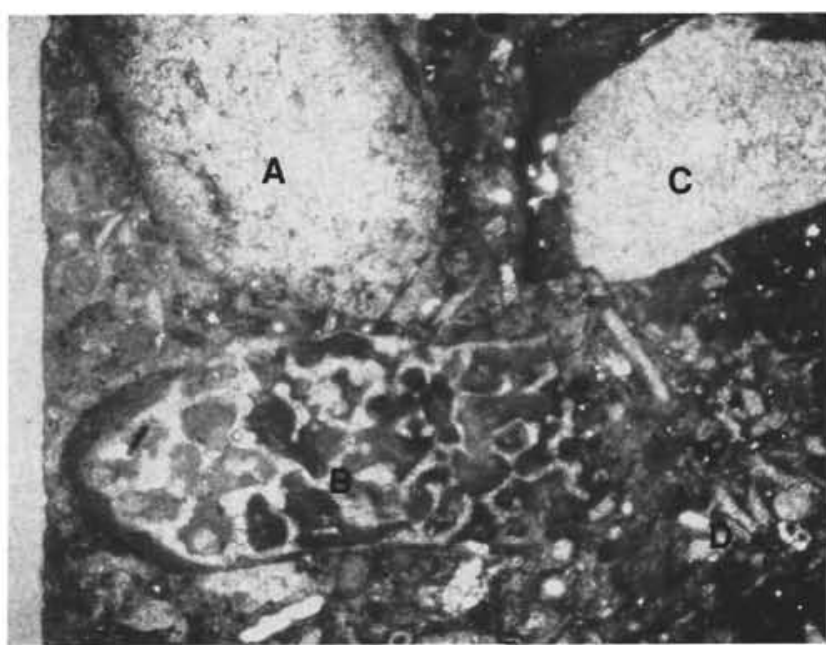

4

$1 \mathrm{~mm}$

Plate 5. Thin-section photomicrographs of Unit VI lithology, Site 764. 1. Sample 122-764B-10R-1, 4-7 cm. Packstone to grainstone. Peloidal foraminifers (A) undergoing neomorphism. Area (B) shows moldic porosity. Pelmatozoans (C) and recrystallized foraminifers (D). Triasina sp.? Note overly close packing texture. 2. Sample 122-764B-12R-1, 43-46 cm. Wackestone to packstone. Dasycladacean algae (A) and (B) with echinoderm (C) in a neomorphic sparry calcite matrix with interspersed shell fragments. 3. Sample 122-764B-13R-1, 3-7 cm (crossed nichols). Moldic porosity in boundstone in a large coral fragment (A). Matrix consists of micritic infillings with pelmatozoan fragments (B). Note allochemical grains with micritic envelopes (C). Large algal fragments were observed within the thin section. 4. Sample 122-764B-19R-1, 2-4 cm. Grainstone. Large rounded algal fragments (A-C), with micritized coatings that are iron oxide stained. Note recrystallization of algal fragments. Fine-grained fossil hash with micrite (D) in matrix. 